\title{
The Comparing Analysis of Sociocultural Background and Mental Illness between Painter Lee Jungseop and Vincent Van Gogh
}

\author{
Young Sik Lee ${ }^{1,2}$ and Hyunchan Hwang ${ }^{1}$ \\ ${ }^{1}$ Department of Psychiatry, Chung-Ang University Hospital, Seoul, Korea \\ ${ }^{2}$ Department of Psychiatry, Uijeongbu Healings Hospital, Uijeongbu, Korea
}

\author{
화가 이중섭과 반 고흐간의 사회문화 배경과 정신질환에 관한 비교 고찰 \\ 이영식 ${ }^{1,2} \cdot$ 황현찬 $^{1}$ \\ 1중앙대학교병원 정신건강의학과, ${ }^{2}$ 의정부힐링스병원
}

The authors have investigated the life, family, premorbid personality, historical background, writings, and dysfunctional behaviors of Vincent van Gogh and Jungseop Lee before hospitalization. Psychiatric symptoms at the time of hospital admission, physical and mental illness, psychodynamic approach, treatment, and artistic creativity were evaluated. The two artists showed characteristics of bipolar disorder and substance use disorder including alcoholism. Van Gogh showed possibilities of bipolar schizoaffective disorder, while Lee had signs of bipolar II disorder. The two artists showed high creative urges in hypomanic states and low creative urges in depressive states. Van Gogh was amenable to psychiatric treatment from the start. Lee, although showed resistance to treatment at first, improved with progressive treatment and continued his artistic endeavors. Artists who are diagnosed with bipolar disorder and individuals close to them require ongoing psychiatric supervision to prevent mood swings, substance abuse, and suicide and continue their artistic work. Also, any discussion related to the artist's creativity and psychiatric disorders should not belittle the artistic achievements by overinterpreting the artist's physical or psychiatric illness or underestimating and ignoring them altogether. The two artists' lives represent a struggle to manifest artistic creativity and goals in life alongside the fight against psychiatric illness and hardship.

Psychoanalysis 2022;33(1):1-18

Keywords: Vincent van Gogh; Jungseop Lee; Psychiatric illness.

Received: October 24, 2021 Revised: January 7, 2022 Accepted: January 10, 2022

Address for correspondence: Young Sik Lee, MD, PhD

Department of Psychiatry, Chung-Ang University Hospital, 102 Heukseok-ro, Dongjak-gu, Seoul 06973, Korea

Tel: +82-2-6299-1505, Fax: +82-2-6298-1508, E-mail: hawkeyelys@hanmail.net

\section{서 론}

당신이 알고있는 외국인 화가를 한 사람 꼽으라면 우리나 라 사람들을 포함한 전 세계인들은 빈센트 반 고흐(Vincent van Gogh, 이하 빈센트)를 뽑을 것이다. 빈센트의 그림은 일 상주변에서 흔히 접할 수 있을 정도로 우리에게 가장 친숙 한 화가이다. 또한 한국 대중들이 가장 좋아하는 한국 화가 를 꼽으라면 이중섭이라는 말에 토를 달 사람은 거의 없다 고 본다. 일 예로 1988년 7월 28일 중앙일보 신문기사에(“초

This is an Open Access article distributed under the terms of the Creative Commons Attribution Non-Commercial License (https://creativecommons.org/licenses/by-nc/4.0) which permits unrestricted non-commercial use, distribution, and reproduction in any medium, provided the original work is properly cited.
중고 학생” 1988) 따르면 8월 동방생명 제8회 전국사생실기 대회 본선 참가자 2,000여 명을 대상으로 실시한 '청소년들 의 미술 성향 조사에서 가장 존경하는 외국 화가의 경우 빈 센트(26.7\%), 피카소(Picasso, 15.3\%), 밀레(Millet, 14.3\%) 순 이었으며, 한국 화가로는 이중섭(27.6\%) 이외에는 다른 화가 들에 대해 모르거나 무관심하여 무응답이 47.7\%였다. 2014년 7월 7일 중앙일보 기사(Kwon 2014)에 따르면 2011년 5월부 터 2014년 5월까지 3년 동안 네이버 지식백과 미술서비스 페 이지뷰를 집계했는데, 국내 이용자들이 가장 많이 본 우리 그 림 10선에 김홍도, 신윤복, 김정희, 신사임당 그리고 이중섭 을 손꼽았다.

두 사람을 연결하는 칭호로 이중섭을 '한국의 빈센트 반 고흐라고 지칭하는 사람들이 있다(EBS Knowledge Chan- 
nel e Creative Team 2015). 특히 고은이 저술한 '이중섭 평전' 에는 빈센트와 이중섭을 비교한 문장들이 도처에 기술되어 있다(Go 2004).

두 사람 모두 생전에는 비참한 생활고에 시달리다 40세 전후에 사망하였고, 사후 얼마 지나지 않아 천재성이 세상에 알려지면서 유명세를 타며 그림값이 폭등하는 드라마틱한 삶을 살았으며, 두 사람간 성격 차이는 있지만 현실 생활 적 응력이나 경제 관념없이 오로지 그림 그리는 것 밖에 모르는 외골수적 순수한 열정의 소유자였으며, 빈센트는 동생 테오 (Theodorus "Theo" van Gogh)와 이중섭은 일본 부인과 장 기간 서신 왕래를 한 편지와 그림들이 책으로 출판되어 그림 이 그려진 엽서 편지라는 문예 장르에 이바지 했다는 공통점 을 가지고 있다. 무엇보다도 정신건강의학과 의사인 저자들 의 관심을 그는 사항은 두 사람 모두 생의 말년에 정신병원 에 입원하였고, 퇴원 후 1 년 이내에 사망하였다는 공통점이 다. 그들의 직접 사인이 빈센트의 경우는 권총 자살, 이중섭 의 경우는 거식증과 알코올중독에 의한 간 혼수였다.

한편 빈센트에 관한 외국 정신의학계의 동향을 살펴보면, 속속 밝혀지는 빈센트의 생애나 그림에 관한 새로운 사실들 과 DSM- 5 를 필두로 한 새로운 정신분류학 체계에 입각한 연 구들이 유명 정신의학 관련 잡지에 현재도 꾸준히 보고되고 있다. Blumer (2002)는 150여 명이 넘는 의사들에 의해 30 개 정도의 의학적 진단이 제기되었다고 하였다. 국내 정신과 의 사에 의한 빈센트에 대한 의학적 연구는 1997년 '정신분석'지 에 실린 이무석의 '빈센트 반 고흐의 생애에 대한 정신분석학 적 조명' 이후 거의 없는 실정이다(Lee 1997).

한편 이중섭의 국내 정신과적 연구를 연차 순으로 정리해 보면 다음과 같다. 1973년 12월 16일 조선일보 기사(“故 李仲 㷔화백” 1973)에 따르면 주치의 유석진은 12월 14일 성모병 원 정신과에서 열린 환자의 그림과 수예품 전람회에서 '그림 을 통해 흩어진 정신을 정화하여 회복되어갔다.'라고 말하며 이중섭의 투병 그림들을 소개하였다. 1985년 3월 임상예술학 보 창간호에 융 분석심리학에 입각한 ‘이중섭 회화의 상징성' 이란 제목의 곽영숙 보고가 있었으며(Kwack 1985), 1993년 7월 9일 중앙일보 기사(Hong 1993)에 따르면 7월 7일 한국 임상예술학회발족 11주년 93국제학술심포지엄에서 '화가 이중섭의 작품과 정신세계'라는 주제의 토의가 있었다. 여기 서 이규동 정신과의원 원장은 어머니와의 강력한 애착관계 와 동그라미 콤플렉스 관련성에 대해 발표하였고, 곽영숙(국 립정신병원)은 스스로에 대한 억압 표현 대치물로서의 (흰소 $>$ 의 상징성에 대해 발표하였다. 토론회는 이중섭은 정신질환 을 앓았음이 틀림없으며, 정신병은 여타 질환과 같은 하나의 병일 뿐 예술세계에 영향을 미치지는 않았다고 결론지었다.
1994년 10월 표현정신병리학회 국제 심포지엄 및 미술요 법 워크샵 '위기와 창조성'이 열렸다. 이때 이부영 정신과 교 수의 '이중섭 회화에서 본 그리움의 의미-위기와 창조성과 의 입장에서'라는 주제의 강연이 있었다(Lee 1994). 이후 20 년 이상 이중섭에 관한 관심은 잠잠하다 2016년 12월 정신 과 전문의 손성은이 '인물미술사학'이라는 잡지에 150페이 지에 달하는 〈이중섭의 심리부검〉이라는 제목의 방대한 글 을 통해 그간 밝혀진 이중섭의 일생과 그림을 통한 정신분 석적 해석, 정신증상 해석, 새로운 진단 모색, 치료과정을 상 세히 기술하였다(Sohn 2016). 하지만 화가 이중섭에 대한 정신의학적 연구 자료는 여전히 충분치 못하다.

이에 저자는 그간 새롭게 밝혀진 사실들과 2013년 출간된 DSM-5 (American Psychiatric Association 2013)로 대표되 는 현대의 정신병리 정신분류학체계 변화에 입각하여 두 화 가의 삶의 궤적과 정신세계를 생물-정신-사회-영적(biopsycho-socio-spiritual) 입장에서 비교 고찰하고자 하였다. 빈센트의 일생에 대한 정보와 그가 쓴 편지들은 박홍규의 〈내 친구 빈센트〉 (Park 1999), 민길호의 〈빈센트 반 고흐, 내 영혼의 자서전> (Min 2000), 김소윤이 번역한 노무라 아쓰 시의 〈고흐, 37년의 고독〉 (Nomura 2004), 남경태가 번역한 주디 선드(Judy Sund)의 〈고흐〉 (Sund 2004), 그리고 에윈 반 미커렌(Erwin van Meekeren)이 쓴 〈Starry starry night: life and psychiatric history of Vincent van Gogh〉 (van Meekeren 2003)를 참고하여 저술하였으며, 책들간 관점이나 내용이 다를 경우 정신건강의학과 의사인 Meekeren이 쓴 영문판을 우선으로 작성하였다. 이중섭의 일생에 대한 정보는 최열의 〈이중섭 평전〉 (Choi 2014), 이활의 〈이중섭(李仲㷧)의 사랑 과 예술〉 (Lee 1981), 고은의 〈이중섭 그 예술과 생애〉 (Go 1973)와 〈이중섭 평전〉 (Go 2004), 강원희의〈천재화가 이 중섭과 아이들> (Kang 1999)을 주로 참고하여 저술하였으며 이중섭의 편지에 대한 정보는 박재삼이 번역한 〈이중섭, 그 대에게 가는 길〉 (Lee 2000), 양억관이 번역한 〈이중섭 편지〉 (Lee 2015)를 참고하였다. 책들간에 이견이 있을 경우 더 최 신판을 참고로 하여 서술하였다. 두 화가에 대한 비교 고찰 의 목적은 크게 세가지로 나누어 볼 수 있다.

첫째, 이중섭과 빈센트의 출생, 성장배경, 화가의 길, 정신 질환 치료, 생의 마감까지의 일생과 그들이 처했던 시대적 환경에 대해 좀더 사실에 입각한 구체적이고 객관적인 유사 점과 차이점을 비교 고찰하여 이중섭 화가에게 왜 '한국의 반 고흐라는 별칭을 붙였는지에 대한 구체적 근거들을 찾아 보고자 하였으며, 본 저술을 통해 독자로 하여금 이중섭에 대 한 관심을 유발하여 이중섭을 널리 알리는데 역할을 해보고 자 하였다. 둘째, 심리부검(psychological autopsy)은 사망자 
의 죽음과 관련한, 혹은 그 죽음을 유발하였을 것으로 추정 되는 정신행동적인 요인들을 규명하여 예방책을 모색하는 작업을 칭한다. 저자는 두 화가의 정신적 문제행동이 발생하 여 치료로 이어지고 사망에 이르는 과정을 정리한 심리부검 ( $\mathrm{Na}$ 등 2015)을 통해 얻은 자료들이 임상현장에서 마주치는 제2, 제3의 빈센트나 이중섭과 같은 또 다른 예술인들에 대 한 정신과적 건강관리나 임상치료에 도움이 되었으면 하는 바램이다. 셋째, 정신과의사로서 예술인의 작품과 생애를 정 신병리, 정신역동학적 나아가 정신질환 혹은 신체질환의 결 과물로 바라볼 것이냐? 아니면 질병이 아닌 순수 예술가의 입장에서 시대를 뛰어넘는 창조적 결과물로 볼 것이냐?는 오랜 논쟁거리이다. 또한 정신과적 치료는 예술가의 작품성 창조성에 어떤 긍정적 부정적 영향을 줄 것이냐?에 대해 두 화가를 통해 생각해보고자 하였다.

\section{두 화가의 일생 요약 비교}

두 화가의 정신세계를 이해하려면 삶의 궤적에 대한 이해 가 필수적이다. 오랜 정체성 혼란 끝에 화가가 되겠다고 결심 한 빈센트의 나이는 27세인데, 일본 유학을 마치고 원산으로 귀국하여 국내에서 화가로 출발한 이중섭의 나이도 27세이 다. 다만 빈센트의 경우 오랜 방황 끝에 직업 화가가 되기를 결심하고 수련을 시작할 무렵에, 이미 이중섭은 일본 유학을 마치고 직업 화가로서의 국내 출발을 했다는 점이다. 따라서 두 화가의 일생을 1) 27세 이전까지, 2) 27세부터 정신병원 입 원 전까지, 3) 정신병원 입원기, 4) 정신병원 퇴원 후 사망까 지, 5) 사망 이후로 나누어 비교 요약하였다. 빈센트의 일생 에 대한 보다 자세한 글은 필자의 종설을 참고하길 바란다 (Lee 2021). 반면 이중섭의 경우는 가장 사실에 입각하여 저 술하였다고 판단된 최열의 '이중섭 평전'을 중심으로 기술 하였다.

\section{본 론}

\section{두 화가의 일생 요약 비교}

\section{화가로서의 인생 전반기(출생-27세)}

두 화가의 인생 전반부를 비교 정리하면 빈센트의 경우 삼촌들은 화상, 부친이 목사인 집안의 장남으로 태어나 최종 학력이 15 세로 종료된다. 이후 화상, 교사, 목사 조수, 서점 원, 신학대 준비생, 탄광 복음전도사로 여러 곳을 전전하다 27세때 비로소 테오의 지원을 받아 직업 화가로서의 수련을 시작하게 된다.

반면 이중섭의 경우는 부농 지주의 막내아들로 태어나 비
록 4세때 아버지가 사망하지만 평양 재력가인 외조부 덕에 평양에서 초등학교를 나오고, 민족학교인 오산고보 졸업 후, 도쿄유학 생활을 한다. 학창시절 잘생긴 만능 예능인(미술 음악 체육)으로서 유명세를 탔고, 고교 일본대학시절에는 매 년 전시회에 입상하여 장래가 촉망되는 화가로 인정받는 상 태에서 원산으로 귀국하여 인생 전반기를 종료한다. 이중섭 은 26세에 문화학원연구생을 마치기까지 20년 학창시절의 선후배 동창 인맥은 인생전반기에 얻은 가장 소중한 자산이 라 하겠다. 빈센트가 27세에 화가의 길로 시작단계인 반면, 이중섭의 경우는 이미 화가로서의 이름이 알려진 상태에서 귀국하여 인생 후반기를 맞이하게 된다.

\section{7세-정신병원 입원 전}

두 화가에 있어 이 시기는 가장 활동적인 시기이다. 빈센트 의 경우 단기간의 브뤼셀 왕립 회화 아카데미, 헤이그(Hague) 의 모베(Anthonij “Anton" Rudolf Mauve)로부터의 가르침, 엔트워프(Antwerp) 미술 아카데미, 파리 코르몽(FernandAnne Piestre Cormon)의 화실, 파리 화가들로부터 인상파 기법, 점묘법, 일본판화의 영향을 받아 다양한 모색을 시도 하지만, 결국 우리에게 익숙한 빈센트 그림을 그리기 시작하 는 화가로서의 정점은 35세인 아를(Arles)에서 부터이다. 하 지만 약혼자가 생긴 후원자 테오, 예술적 동반자라 여긴 고 갱(Paul Gauguin)이 떠날 것이라는 극도의 불안은 결국 자 해사건으로 터져 정신병원에 입원하게 된다.

이중섭이 도쿄에서 귀국한 시점은 태평양전쟁이 한창 진 행 중이던 1943년 8월이었다. 2년 뒤 마사코가 현해탄을 건 너와 29세에 결혼식을 올렸고 3개월 뒤 해방을 맞는다. 북한 체제 생활에 적응하던 중 형이 사상적 이유로 실종되고, 한 국전쟁 소용돌이 속에 1950년 12월 남쪽으로 피난길을 떠난 다. 풍요로운 환경에서 고등교육을 받고 국제결혼을 한 이중 섭 부부에게 피난민의 현실은 가혹했다. 부산-서귀포-부산 을 오갔지만 경제적 궁핍함으로 결국 부인과 두 아들은 1952년 7월 일본으로 떠났다. 얼마 후 일본서적을 거래하려 다 사기를 당하여 생긴 빚은 부부의 큰 짐이 되었다. 36 세 혈 기왕성한 나이에 경제적 문제로 가족과 생이별을 하고 혼자 남겨진 이중섭은 화가 문인 친구들의 도움으로 부산, 통영, 마산, 진해, 진주, 서울, 대구를 오가며 활발한 작품활동을 하였다. 특히 통영은 명작 탄생이 시작되는 시기이며, 이어 서울에 상경하여 개인전을 준비하는 1954년은 이중섭 예술 의 절정기라 하겠다. 전시회에서 팔린 그림으로 당당하게 가 족을 방문하려는 39세 화가의 1955년 1월, 생애 최대의 미도 파 개인전은 대성황리에 끝났지만 수금이 전혀 안되고 오히 려 뒤풀이잔치 빚만 남게되었다. 재기를 노린 4월 대구 미공 
보문화원 개인전마저 흥행에 실패하자 아내가 진 빚을 갚을 돈을 마련하여 일본으로 가려는 계획은 좌절되고, 절망에 빠 진 이중섭은 결국 7월 대구성가병원에 입원하게 된다.

\section{정신병원 입원 생활}

1888년 크리스마스 이브에 빈센트는 정신착란 상태에서 자신의 왼쪽 귓볼을 잘라 신문지에 싸서 창녀 라셀(Rachel) 에게 선물하였고, 놀란 라셀은 경찰에 신고하여 경찰은 다음 날 상처 입은 채 침대에 누워 있는 빈센트를 병원으로 데려 갔다. 1주일만에 회복되어 집으로 퇴원했지만 1889년 2월 둘 째 주에 다시 환청, 환시, 피해망상에 사로잡혀 1 주간 입원 후 퇴원하였다. 빈센트의 이상행동에 불안을 느낀 주민들이 시장에게 탄원서를 제출하여 3월 병원에 다시 입원해야 했으 며, 경찰이 집을 폐쇄하고 외출 시 감시하는 사람이 동반되는 처지가 되었다. 1889년 5월 8일 아를을 떠나 조용한 수도원 분위기를 풍기는 인근 생레미(Saint Remy de Provence)의 정 신병원에 자발적으로 입원했다. 식사는 다른 환자와 함께했 으나 침실은 독실을 사용했고 화실로 사용할 2 층의 별실도 부여 받았다. 1889년 12월 크리스마스 무렵 1주일간, 1890년 1월 21일부터 1주일간, 1890년 2월 23일부터 65일간의 가장 긴 정신적 위기상황을 생레미 정신병원에서 맞이한다. 정신 적 위기 상황 중간에는 맹렬한 그림 작업이 이루어진다. 1890년 5월 퇴원할 때까지 1년간 생레미 정신병원에서 이틀 에 1점씩 150 여 점의 유화를 그렸다.

이중섭의 경우 1954년 1월 전시회의 금전적 실패 후, 2월 대구로 내려오면서 정신이상 증세를 보여오다가 결국은 입 원할 수 밖에 없게 된 시기는 1955년 7월이다. 대구 경찰서 사찰과장이 “나는 빨갱이가 아니다"라고 자수한 이중섭을 정 신병자로 보고 구상에게 연락하여 대구성가병원에 2개월 입 원시켰다. 1955년 8월 26일 서울에서 온 이종사촌형 이광석, 친구 김이석, 구상과 함께 서울로 상경한다. 이광석 집에 며 칠 머물다 거식증 등 정신증상을 감당키 어려웠고, 이광석 역 시 해외연수를 떠나야하는 문제로 이중섭은 종군화가라는 신분으로 구상과 차근호의 주도하에 1955년 9월 2일 수도육 군병원에 1 달간 입원하여 정신과 군의관 유석진 소령에게 맡겨진다. 이어 개업한 유석진 주치의를 따라 9월말 성베드 로병원으로 전원을 가서 3개월 입원 후 증세의 호전을 보여 12월말 퇴원한다. 1차 입원은 3군데 정신병원으로 1955년 7 월부터 12 월까지 총 6 개월에 걸친다. 빈센트의 경우 아를병 원 입퇴원 반복 5 개월, 특히 생레미 정신병원에서 12 개월 병 원생활을 하며 정신이 회복된 기간에 대표작들을 완성해 나 갔다. 이중섭의 경우 비록 회화작업을 할만한 병실 환경 여 건이 못되었지만, 자신의 심리치료 과정을 표현한 낙화(낙서
화)를 남겼다.

\section{퇴원후-사망}

오랜 병원생활과 북쪽을 향한 그리움은 주치의와 테오 동 의 하에 1990년 5월 퇴원하여 파리인근 오베르-쉬르우아즈 (Auvers-sur-Oise)에 거주하는 인상파 후원 정신건강의학 과의사 가셰(Paul-Ferdinand Gachet, 1828-1909)에게 맡겨 진다. 빈센트는 오베르 도착 이튿날부터 마치 자신이 시한부 생명이라도 되는 듯 야외에서 맹렬히 그림을 그리기 시작했 다. 뚜렷한 정신 발작없이 오베르에 머문 2개월 간 평균 하루 1점 이상, 80점 이상의 그림을 완성했다. 오베르에서의 특징 은 정사각형을 두개 이은 크기의 긴 장방형 캔버스를 사용하 여 파노라마처럼 밀밭 풍경을 그리기 시작하였고 반면에 나 무, 나무뿌리, 보리 짚단, 밀 이삭 등을 매우 가깝게 화면 가 득 그려 생레미에서 그린 〈붓꽃〉 이상으로 응축된 느낌을 강 조했다. 누에넨(Neunen) 시절 그렸던 탑과 묘지의 습작과 유사한 〈오베르의 교회〉가 탄생된다. 〈라부(Ravoux)의 딸〉, 〈가셰의 딸〉 등 초상화를 그렸으나 오베르에서는 자화상을 그리지 않았다.

6월 8일 가셰의 초대를 받은 테오 부부가 오베르를 방문 하여 즐거운 시간을 보냈으나, 6월 30일 테오의 아들이 아프 다는 소식이 전해지자 걱정이 된 빈센트는 7월 6일 파리의 테오를 방문한다. 갓난아이와 5층 아파트에서 경제적으로 힘겹게 사는 테오 부부를 직접 보고는 절망에 빠진다. 여름 휴가를 오베르로 오라는 빈센트의 요청 대신 테오는 네덜란 드로 간다는 편지를 보낸다. 점차 테오와의 관계에서 불안과 실망이 커져갔다.

빈센트는 죽기 5일 전인 1890년 7월 24일 테오에게 유사 한 내용의 편지를 두 번 썼다. 첫 번째 편지는 7월 27일 빈센 트가 자살시도 당시 지니고 있었고, 두 번째 편지는 첫 번째 편지를 수정한 것으로 테오에게 보낸 마지막 편지이다. 첫 번째 편지에는 "테오. 너는 단순히 그림을 파는 화상이 아니 라 형을 통해 직접 그림을 제작하는 일에 참여하고 있고, 최 악의 상황에도 그림들은 남는다"는 결연하고 비장한 내용이 어서 일부 사람들은 자살을 암시한 편지라고 주장하였다. 반 면 같은 날 수정한 두 번째 편지는 "지금 나는 모든 정신을 집중하여 그림에 몰두하고 있다. 편지에 4점의 스케치(도비 니 정원, 초가집, 밀밭 2점)와 화구 구매 목록을 동봉한다." 는 전혀 자살과는 먼 내용의 편지였다. 흔히들 〈까마귀 나는 밀밭>이 자살 순간에 그린 그림이라는 주장이 있는데, 사실 은 이 그림 뒤에도 빈센트는 12점을 더 그렸다. 7월 27일 들 판에서 자살 시도로 상복부에 총상을 입은 빈센트는 피를 흘리며 하숙집으로 돌아왔다. 테오가 도착하였지만 빈센트 
는 더 이상의 처치를 거부한 채 7월 29일 새벽에 사망한다.

이중섭은 1955년 12월 성베드로병원 퇴원 이후 북한산 근 처의 성북구 정릉에 화가 한묵과 살게 되었다. 표면적으로는 명동다방에 출입했고, 여러 친구들을 만나 술판을 벌이고 자 주 싸움판이 벌어졌고, 이전처럼 인사동의 골동품에 관심을 가졌다. 하지만 가족관계는 1955년 12월 중순 퇴원 전 부인에 게 "도쿄에서 가족들이 오거나 내가 가는 방법을 잘 조사해서 완벽하고 빠른 길을 찾아보자”고 보낸 편지를 마지막으로 사 망하기까지 부인이 보내온 편지를 보지도 보내지도 않았다.

1956년 5월 식사거부로 인한 영양실조, 황달, 간염, 정신 이상으로 인해 한묵, 박고석에 의해 7월초 청량리뇌병원 무 료병동에 입원하게 된다. 7월 중순 신체적 상태가 위독하여 구상과 차근호에 의해 적십자병원 내과로 전원하게 된다. 8월 퇴원하여 잠시 노고산 고모집에 있다가 병세가 악화되 어 적십자병원에 재입원 치료 중 9월 6일 사망한다. 두 화가 모두 퇴원 후 얼마 지나지않아 사망하였다. 빈센트의 경우 퇴원한 지 3개월 후, 비록 주변에 정신과의사가 있었지만 갑 자기 권총자살로 사망하게 되고, 이중섭은 별 치료없이 방치 되어 지내다 폭음으로 인한 간질환이 악화되어 9월 6일 정 신병원 퇴원 9개월 만에 사망하게 된다.

\section{사망 이후}

가셰가 빈센트의 데스마스크를 스케치했고, 빈센트가 그 림을 그렸던 1 층 방에 그의 그림들이 걸려 고별식장이자 회 고전시장이 되었다. 1890년 7월 30일 자살이라는 이유로 종 교적 의식없이 공동묘지에 매장되었다. 가족 누구도 빈센트 의 그림에 관심이 없어서 테오 혼자서 그림들을 모두 상속 받는다. 테오는 형이 죽은 6개월 후 매독 합병증으로 사망한 다. 빈센트의 제수 요한나(Johanna Bonger)는 남편이 소지 했던 빈센트가 보낸 편지 약 600통을 정리하여 1914년 네덜 란드어로 출판했으며 남편의 묘를 형 옆으로 이장한다. 요한 나 사망 2년후 1927년 영어판 편지집이 출간된다. 1905년 이 후 마티스(Henri Matisse), 블라맹크(Maurice de Vlaminck) 등의 야수파와 키르히너(Ernst Ludwig Kirchner), 헤켈(Erich Heckel)의 독일 표현파를 중심으로한 추종자들에 의해 서 빈센트 반 고흐 전시회가 경쟁적으로 개최되었다. 1960년 조카 빈센트(Vincent Willem van Gogh)에 의해 반 고흐재 단이 설립되었고, 1973년 6월 2일 암스테르담 고흐 미술관이 개관되었다.

이중섭은 무연고자로 처리되어 3일간 영안실에 안치되었 고, 1956년 9월 11일 홍제동 화장터에서 화장 및 장례를 치 루었다. 봉은사에 봉안되었던 유골은 11월 18일 묘비제막식 이 열린 후 망우리 공원에 묻혔다. 유골 일부는 정릉 청수동
계곡에 뿌리고, 일부는 1957년 9월 6일 구상이 마사코에게 전달하여 가족묘지에 안장하였다. 1960년 부산 로터리다방 에서 최초의 유작전이 열렸다. 1972년 현대 화랑에서 15주기 기념 유작전과 작품집이 출간되었고, 일대기를 다룬 영화 연 극이 상영되었다. 1975년 11월 구상이 주축이 되어 '이중섭 기념사업회'를 발족하고, 1989년 제1회 '이중섭 미술상'을 시 상하였다. 1978년 부산국제화랑에서 미발표된 이중섭 작품 전이 개최되었으며, 10월 은관문화훈장을 받았다. 1979년 마 사코가 소장하였던 그림엽서, 은지화 전시회가 서울, 대구, 부산에서 열렸고, 1980년 이중섭이 아내와 두 아들에게 보 낸 편지가 번역되어 출판되었다. 1986년 서울 호암갤러리에 서 사후 30 주기 기념 250여 작품이 전시된 회고전이 열렸다. 1997년 9월 제주도 서귀포시가 이중섭거리 선포 및 이중섭 거 주지를 복원하여 개관하였다. 2002년 11월 이중섭전시관이 개관되었다. 2003년 가나아트 이호재 대표로부터 이중섭 원 본 8점과 동시대 화가 30명의 작품 52점을 기증받고 2종 미 술관으로 등록되었다. 2004년 갤러리 현대 박명자 회장이 < 파란게와 어린이> 외 동시대 화가 작품 54점을 기증받아 제 1 종 미술관으로 등록되었다.

사후 두 화가 모두 편지집이 출판되었고, 독립된 미술관을 가지게 되었다. 빈센트의 경우 제수와 조카의 역할없이는 불 가능 하였고, 이중섭의 경우도 부인, 구상을 비롯한 문인 화 가 친구들의 역할이 결정적이었다고 본다.

\section{두 화가의 가족배경}

빈센트의 친할아버지(1789-1874)는 신학교육을 받은 유명 한 신학자이며 목사였다. 아버지 테오도루스(Theodorus van Gogh, 1822-1885)는 신학 공부를 마치고 쥰데르트(Zundert) 교구 목사가 되었다. 아버지만큼의 명성은 없으나 점잖고 성 실하고 모범적이며 책임감있게 목사의 역할을 하였다고 한 다. 빈센트와 대립각을 세웠던 부친은 자택에서 빈센트가 32 세때 심장마비로 사망하였다. 모친 카르벤투스(Anna Carbentus, 1819-1907)는 온화한 성격의 소유자로 그림에 소질 이 있었다고 알려져 있는바 빈센트의 그림에 관한 흥미는 모 친으로부터 온 듯하다. 빈센트는 3명의 친삼촌이 있었는데 모두 화상이었다. 1851년 헤이그에서 결혼한 부모는 1년 후 에 사산된 아이를 출생하고, 이어 6남매를 출산한다. 첫째 여 동생 안나(Anna Cornelia van Gogh, 1855-1930)는 빈센트 가 영국에 있을 때 같이 있었는데, 이후 사이가 멀어져 별 교 류는 없었다. 남동생 테오(1857-1891)는 빈센트의 평생 조력 자로 빈센트 사망 6개월 후 사망한다. 심약하고 우울증을 않 았다고 알려져 있다. 둘째 여동생 엘리자베스(Elizabeth "Lies" van Gogh, 1859-1936)는 빈센트와 생전에 별로 친하지 않았 
으나 빈센트 사후 회고록을 저술하였다. 셋째 여동생 빌레미 나(Willemina "Wil" van Gogh, 1862-1941)는 빈센트와 가장 가까웠던 여동생으로 편지 왕래가 잦았다. 조현병으로 정신병 원에 입원하여 79세에 정신병원에서 생을 마쳤다고 한다. 막 내 남동생 코르넬리(Cornelis "Cor" van Gogh, 1867-1900)는 결혼 실패 후 전쟁에 지원하였다가 자살했다고 알려져 있다. 가족의 정신병력은 빈센트의 6형제 중에서 4명(빈센트 반 고 흐, 테오, 빌레미나, 코르넬리)이 정신질환력이 있으므로 유 전부하가 높은 기분장애가 추측된다(Lee 2021).

이중섭의 조부(이창희)는 성격이 활달한 평원군 조운면 송천리 700석 부농이었던 반면, 부친(이희주)는 문약하고 폐 쇄적인 인물이었다. 외조부(이진태)는 평양의 개화기 경제를 주름잡던 실력가였고 모친 이씨는 그의 둘째 딸로 외조부의 성격을 이어받아 원예 축산에 능통한 여장부였다. 약한 부친 은 막내 이중섭이 3세때인 1918년 30세 나이로 11세 위 장남 (이중석), 5세위 장녀(이중숙)를 남기고 사망한다. 이중섭 평 전에서 '부친은 평소 아내에게 모든 집안일을 맡겼고, 우울 한 나날을 보내다가 임종이 가까워지자 분열증이 극심해져 천정의 일정한 곳에만 눈 초점이 고정되고 몸을 움직이지 않 은 채 세상을 떴다'고 기술되었다(Go 2004). 이는 정신병적 우 울증에서 보이는 우울 혼미(depressive stupor) 혹은 조현병에 서 보이는 강경증적 혼미(catatonic stupor) 증상으로 이중섭에 서도 말년에 이와 유사한 증상을 보였다는 시인 김광림의 증
언은 유전적 연관성을 강하게 제시한다고 하겠다(Kim 1977). 형 이중석은 조부의 성격을 물려받아 사업가로 집안을 이끌다 가 해방 후 토지개혁으로 토지를 몰수당하고 행방불명 되었 다. 누나 이중숙은 어린 나이에 출가하였고 조카 이영진, 이 종사촌 이광석 부부, 이종사촌 이효석은 남하하여 이중섭의 생계를 도와주었다(Figure 1).

부인 이남덕 야마모토 마사코는 일본재벌 미쓰이 계열사 의 창고주식회사 사장의 네딸중 셋째딸로 가톨릭 집안이었 다. 1945년 4월 국내로 들어와 5월 원산에서 결혼한다. 첫째 아들은 돌이 채 안되어 디프테리아로 사망하였고, 1947년 여 름 둘째 태현, 1949년 봄 셋째 태성이 태어났다. 1952년 7월 부산 피난시절 일본인 수용소에서 두 아이와 함께 일본으로 귀환하였고, 1953년 7월 1주일간 이중섭이 도쿄에서 재회한 것이 마지막 만남이었다.

\section{병전성격, 인간관계}

의학적 관점에서 빈센트의 성격에 대한 첫 언급은 1950년 대 간질 환자들의 독특한 성격에 대한 연구이다. Gastaut는 1956년 빈센트 특유의 끊임없이 논쟁하여 상대방을 질리게 하는 점액질(viscosity)적 성격, 과필증(hypergraphia), 이타 적 과사회성(hypersocial), 종교적 과몰입, 극단의 양면성이 동시에 존재하는 성격을 전형적인 측두엽간질 성격이라고 주 장하였다(Gastaut 1956). Mehlum은 최초로 빈센트 진단에 경

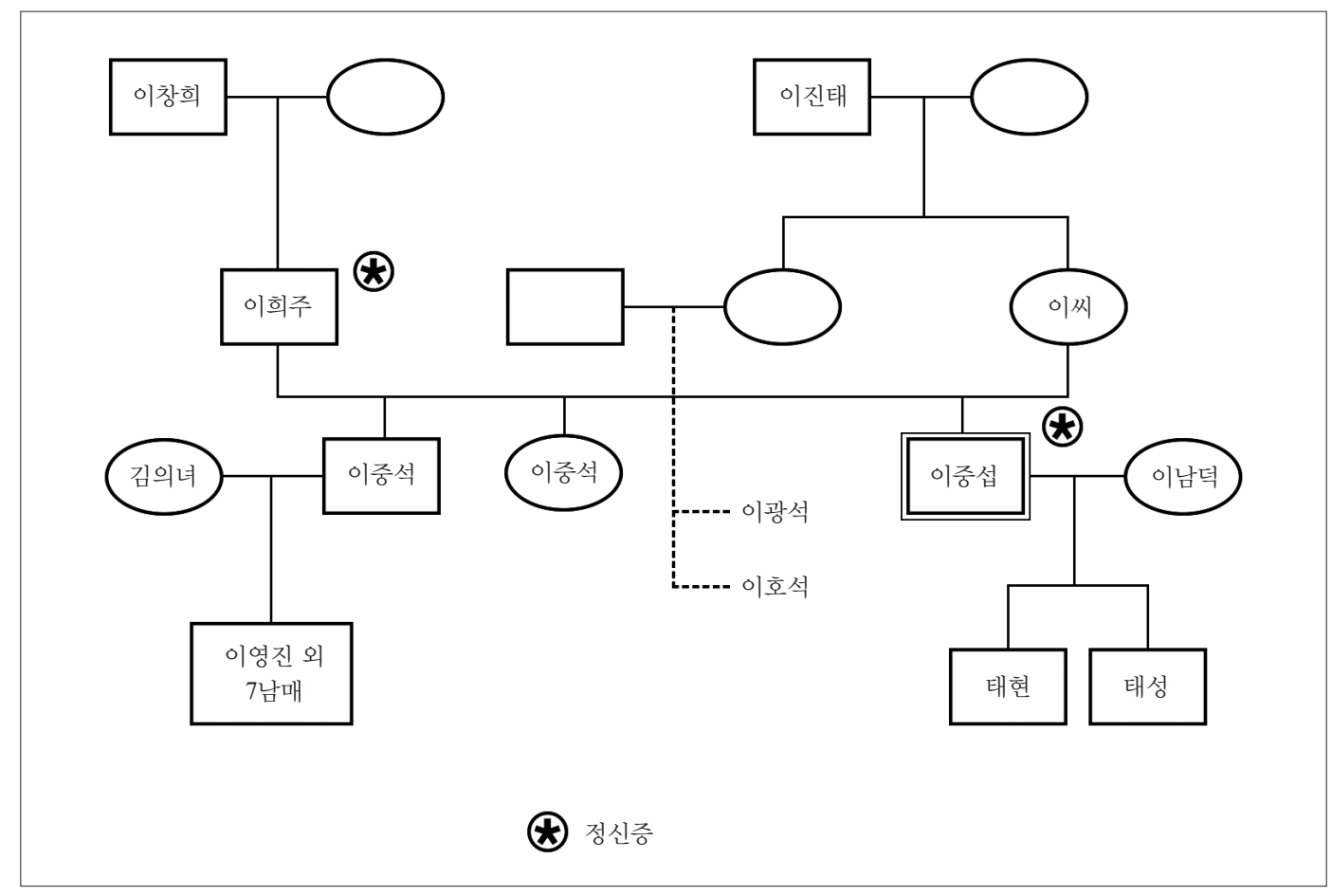

Figure 1. Family tree of Jungseop Lee. 
계성인격장애를 제안하였다(Mehlum 1996). 저자 역시 DSM-5 경계성성격장애 증상 9가지 (1) 버림받지 않으려는 필 사적 노력, (2) 과대평가-과소평가의 극단, (3) 자신의 정체성에 대한 불안, (4) 자신을 손상시킬 충동적 행동, (5) 자살/자해, (6) 기분의 불안정성, (7) 만성적 공허감, (8) 분노조절 못함, (9) 일 시적 피해사고나 해리증상 중 5 개 이상의 진단기준을 빈센트 가 만족시킨다고 판단된다.

이중섭은 다소 예민하고, 사색적이며, 내향적이고, 순한 타협적 성품이었던 것으로 파악된다(Sohn 2016). 회를 먹을 때조차 생선에게 미안해 하였고, 잡아먹은 수많은 '게'들에게 미안한 마음에 평생에 걸쳐 '게'를 그렸거나, 소 판돈을 도둑 맞고 망연자실한 사람에게 마치 자기가 훔친 것처럼 돈을 쥐 어주고 도망치거나, 돈을 받으러 갔다가 불쌍해서 매번 빈손 으로 돌아오는 일화(Jo 1971)로 미루어 보아, 상대방의 입장 에서 고통을 공감하는 측은지심이 큰 성격이라 생각된다. 아 랫사람에게도 형이라 존칭할 정도의 겸손과 말수가 적고, 단 정적인 확실한 이야기를 하지 않으며 말머리만 꺼내놓고 고 개만 그떡이며 상대방에 동의를 구하는 친화력으로 인해 항시 주변에 사람들이 모여드는 성격이었다(Kim 1977; Lee 1981). 다만 음주 후 보이는 감정기복, 억제된 분노의 폭발, 기분 상 승에 따른 무절제한 금전 지출이 문제였다.

대인관계 측면에서 두 화가의 성격은 대조적이지만 공통 점은 항시 때와 장소를 가리지 않고 그림을 그리게 만든 경험 의 가치에 대한 강박적인 추가이다. 자신이 체험한 대상의 느 낌을 완벽하게 그리기 위해 소를 관찰하다 소도둑으로 몰리 거나, 신혼방에 닭을 가져와 관찰하다 이가 옮아 고생한 이중 섭의 행동은 상상이나 기억이 아닌 직접 관찰하여 그림을 그 려야 한다고 고갱과 설전을 벌인 빈센트의 일화와 맞물린다.

\section{시대적 배경}

1853-1885년 빈센트가 네덜란드에 거주할 당시 네덜란드 는 왕정에서 탈피하여 의회법치주의, 자유주의, 산업화가 활 발히 진행되던 시기였다. 파리 거주 시작해인 1886년은 파 리 만국박람회를 통해 들어온 일본판화(우끼요에)가 미술계 에 알려지면서 인상파에도 영향을 주었지만, 인상파 자체는 퇴조하여 인상파의 종료를 의미하는 마지막 전시회가 열렸 다. 1851년 12월 쿠데타로 나폴레옹3세가 등극하였고, 1871 년 프러시아와 전쟁으로 파리가 함락되고 제 3 공화정이 들어 서는 격변기가 있었다. 빈센트와 가깝게 지냈던 지인 중에는 열렬한 공화파도 있었지만 빈센트는 정치에는 관심이 없었 다(van Meekeren 2003).

이중섭은 일제강점기인 1916년 출생하였다. 도쿄유학 7년 (1936-1943)간 1937년 중일전쟁, 1941년 12월 7일 진주만 기
습으로 시작된 태평양전쟁을 겪게 된다. 식민지 치하의 조선 인으로 정체성 갈등과 징병문제 스트레스를 받았을 것은 명 확하다. 1945년 해방을 맞이하였지만 사망하기까지 10년간 한국전쟁(1950-1953)으로 인한 사상적 갈등, 피난생활(1950년 12월부터), 가족과 이별(1952년 7월부터)로 인한 스트레스는 1956년 9월 사망시까지 이어진다.

빈센트는 전쟁과 정치적 혁명 분위기를 벗어나 평화로운 시대적 환경에서 삶을 살았지만, 이중섭은 20년간을 전쟁이 라는 격변의 시기에 살았다. 특히 "나는 빨갱이가 아니다"라 며 경찰서에 자진 출두한 행동은 사상검열에 대한 스트레스 가 컸음을 반증하는 실례라 하겠다.

\section{정신병원 입원 전 문제행동들}

빈센트의 첫 문제행동은 20대 초반에 짝사랑한 하숙집 딸 에게 거절당한 후 발생한 심각한 우울증이었다. 이후 빈센트 는 종교에 빠져들고 직장에서 해고된다. 이후 여러 거주지와 직업을 전전하며 아버지를 포함한 주변인들과의 문제를 계 속 일으킨다. 목사 자격증을 따기 위해 시작한 라틴어 공부 에 회의를 느껴 포기한 뒤, 별 자격증 없어도 목회 활동이 가 능한 3개월 복음 전도사 교육을 받은 후 벨기에 남부 탄광 지대인 보리나주(Borinage)에서 전도사로 일을 했을 때도, 비참한 생활을 하는 광부들과 지나치게 어울리며 걸인인지 전도사인지 구분이 안될 정도의 과한 행동으로 인해 전도사 의 품위를 훼손한다는 이유로 26 세 때 전도사에서마저 해직 된다. 이종사촌에게 끈질기게 구혼을 요청하다 거절되자 등 잔불에 손을 넣는 자해소동을 벌였으며, 이후에도 스토커 수 준으로 집착을 보였다. 전도사 해직 전후 보인 문제행동, 이 종사촌에 대한 문제행동으로 아버지는 빈센트를 정신병동에 입원 조치하려고 하였다(Arnold 1992). 이후 빈센트가 3살 연상의 아이 딸린 임신한 창녀 시엔(Sien)과 결혼하겠다고 하자 아버지는 법적 보호조치를 취하려 하였고 빈센트는 강 력히 저항하였다. 대인관계에서의 격한 대립은 스승이었던 모베, 친구 라파르트(Anyhon van Rappard)와의 관계에서도 벌어진다. 모베와는 시엔과의 관계에 대한 격한 논쟁 후, 라 파르트와는 작품에 대한 비평에 분노한 후 단절이 발생한다.

자기 징벌적인 신체에 대한 자학행동도 흔하였다. 신학대 학 입시 준비 중 신체적 자학행동을 보였고, 전도사 해직 후 에는 $100 \mathrm{~km}$ 이상을 1 주일 넘게 걸어서 전도사 임명자를 찾 아가거나, 존경하는 화가 브르통(Jules Breton) 집으로 수일간 걸어갔다가 그냥 되돌아온 적이 있었다. 파리에서는 인상파 화가들과 무절제한 과음과 퇴폐적인 생활로 바뀌며 감정기 복, 경조증, 알코올로 인한 행동 문제가 자주 발생하였다.

이중섭은 비록 아버지가 3 세때 사망하였으나, 유복한 가정 
의 막내로서 외조부의 후원 아래 어린 나이 때부터 모친과 떨 어져 중학교, 일본유학까지 모든 과정을 소위 ‘학내 스타’로서 잘 수행하였다. 귀국하여 결혼하고 두 아들을 출산하기까지 아무 문제가 발생하지 않았다. 하지만 한국전쟁으로 인한 피난 생활과 가족과의 이별은 이중섭이 겪어보지 못한 고통이었다. 결국 1952년 7월 우울증이 찾아와 그림 그리는 일이 무의미하 며 자신의 재능을 비하하는 말을 하였다고 한다(Lee 1981). 자 신의 성기에 소금을 뿌리는 행동이 관찰되곤 하였다. 지인에 따르면 농담인지 진담인지 모르겠지만 사용안하고 두면 썩을 까봐 소금에 절인다고 하였다. 또 다른 기이한 행동은 서울에 서 생활할 때 둥근 것을 보면 갑자기 매료되어 흥분하다가 공 포를 느껴 달아나버리는 일종의 강박적 원형콤플렉스 행동 으로 대상은 매우 광범위했다. 시인 김종문은 함께 술을 마시 다 둥근 안주 접시, 둥근 술잔을 한참 보고는 달아나는 이중 섭의 행동을 도저히 알 수 없는 수수께끼라고 했다. 아내의 발가락에 대해 '발가락군', '아스파라거스군'이라고 애칭하여 불렀듯이 이중섭에게 둥근 것은 여성의 부드러운 신체 유방, 엉덩이, 성기를 연상시킨다. 30 대 성적으로 왕성했던 이중섭 에게 이성에 대한 관심과 욕구를 스스로 두려워하고 피하는 심리는 자발적 거세, 거세불안, 죄책감과 관련이 있으며 발병 후의 자학증, 결벽증과 맥락이 상통한다고 생각한다.

본격적 정신이상 행동들을 보이기 시작한 계기는 서울 개 인전(1955년 1월 18일-27일)의 금전적 실패이다. 일생일대 의 계획된 개인전은 비록 은지화 그림들이 외설스럽다하여 경찰에 의해 강제 철거되었지만, 20여점의 작품이 팔리고 세 인들의 관심을 끈 대성공이었다. 하지만 전시회 10 일간의 술 잔치 결과는 참담하였다. 수금이 안되어 아내의 빚도 못 갚 고 외상 술값만 남게 되었다. 곤경에 처한 이중섭은 대구에서 한번 더 개인전을 하자는 구상의 권유대로 2월 24일 대구로 내려온다. 구상은 이중섭의 발병 시점을 7월 성가병원 입원 직전으로(Gu 1974), 조정자는 대구전시회(1955. 4. 11-4. 16) 이후 최태응의 집인 칠곡에서 머물던 5월경으로 보았고(Jo 1971), 고은은 대구전시회가 열리기 전 대구 여관 생활시절 부터인 2월말까지 거슬러 올라간다고 하였다(Go 1973). 발 병 시점과 정신이상 행동들에 관해서는 대구여관과 칠곡에 서 계속 같이 생활했던 최태응의 증언이 가장 신뢰할만 하지 만, 이를 종합하여 볼 때 발병 시점은 고은의 주장이 가장 맞 다고 보여진다.

발병 당시 이중섭이 보였던 기이한 행동들을 열거하면 다 음과 같다. 여관방에서 밤새 가족사진을 보고 징징 울었고, 칠곡 최태웅 집에서도 밤새 가족을 부르는 잠꼬대를 하였다. 새벽에 일어나 칠곡 매천동 거리의 쇠똥을 치우고, 동네 아 이들을 목욕 시키고, 본인이 묵던 여관의 복도를 걸레질하고,
남의 고무신 운동화를 깨끗이 빨아 말리곤 했다. 이러한 행 동을 하는 이유는 "공밥을 먹기 싫어서, 화가랍시고 세상을 속이는 것보다 깨끗이 청소하는 일이 좋아.”라고 하였다. 대 구 개인전 직전에는 "내 그림은 가짜다", "내 소는 스페인 투 우야”, “남덕이 네가 밉다.”라고 외치는 바람에 주변인들은 이중섭을 전시장 밖으로 내보내는 일이 벌어졌다. 개인전시 회가 한창이던 1955년 4월 14일에는 느닷없이 가톨릭 교인 인 구상에게 집에가서 읽어보라는 편지에는 "저의 모든 잘 못을 씻고 예수 그리스도님의 성경을 배워 깨끗한 사람이 되고 싶습니다.”라고 적혀 있었다. 걸핏하면 “포대령 이기련 이 나를 죽이러 온다.”고 숨고, 사람이 웅성대도 누가 잡으러 온다며 피하고, 경적소리에도 깜짝 놀라 도망가는 일이 자주 벌어졌다. 부산에서처럼 “성기에 소금을 뿌려 썩지 않게한 다.”는 이상 행동과 “넌 종군기자이니까 정신병에 특효인 해 골을 쉽게 구할 수 있지않는냐?”라고 최태응에게 부탁한 적 도 있었다. 자신의 그림을 우물에 던져 넣거나 "가짜 그림들 아, 잘 타거라."며 불태우는 소동을 벌인 적도 있었다. 1955년 2월 20일 대구로 떠나기 직전 서울에서 쓴 편지를 끝으로 대 구 체류기간 동안 1 통의 편지도 부인에게 쓴 적이 없으며 부 인의 편지가 와도 뜯어보지 않았다. "내 손가락이 미워서 그 래. 가짜 그림만 그리고 거짓부렁만 하는 손.”이라고 중얼거 리며 자신의 손을 피가 나도록 문지르는 이상한 행동과 "두 번째 단추가 보인다. 그러면 밥을 먹지 말라는 신호야.”라는 알 수 없는 말을하며 음식을 거부하는 행동을 보였다.

두 화가의 입원 전 문제행동 중 보는 관점에 따라 논란이 있을 수 있는 문제는, 우울증에 뒤이은 기분 반등(rebound) 에 의한 경조증, 조증에 관한 언급이다. 빈센트의 경우 20대 초반 실연당한 후 발생한 우울증은 사회생활을 못할 정도로 심각하고 상당기간 지속되었지만, 이중섭의 첫 우울증은 36 세때 가족을 일본으로 보낸 그 해 겨울에 발생한다. 두 화가 모두 경조증, 조증에 대한 언급들이 있는 바, 빈센트는 본고 의 진단파트에서 이를 좀더 언급하고, 이중섭은 본고의 편지 를 통해 얻을 수 있는 자료 파트에서 부연 설명하였다.

\section{입원 시 보인 증상과 질병 경과}

빈센트는 1888년 귀를 자르는 자해사건을 포함하여 대략 6번의 심각한 정신적 위기를 겪는다. 위기란 의식변화에 따 른 기억상실, 혼돈, 환청, 피해망상, 자살, 자해행동을 지칭한 다. 반면에 위기 사이에는 놀랄 정도의 빠른 회복과 명석함 을 편지나 그림 그리기를 통해 증명하였다. 그 기간에도 기 분기복이나 기분부전은 있었으리라 추정된다. 큰 위기상황 을 중심으로 시간적 순서로 정리해보면 아래와 같다. 첫 번 째 위기는 아를병원에서 1888년 12월 23일부터 1주간이었 
다. 왼쪽 귓볼을 칼로 자른 빈센트는 다음날 24 일 아를병원 에 입원하게 된다. 두번째 위기는 아를에서 1889년 2월 9일 부터 1주간이다. 빈센트는 다시 피해망상에 사로잡혔다. 이 번 발작은 그간 아를에서 보호자 역할을 해오던 친구 룰랭 (Joseph Roulin)이 마르세이유(Marseille)로 전근을 가게 되 어 홀로 남게 된 불안한 상황과 연관되었을 가능성이 높았 다. 세번째 위기는 생레미병원에서의 1889년 7월 16일부터 45일간이다. 아를 방문 후 재발하였다. 테오 부인으로부터 자신이 임신했으며 테오의 건강이 염려된다는 말을 듣게 된 다. 얼마 후 야외에서 그림 작업 중에 발작이 시작되어 5일간 지속하였고 자살을 기도하였다. 네번째 위기는 생레미병원 에서의 1889 년 12 월 24 일부터 1 주간이다. 자해사건 1 주년 반 응(anniversary reaction) 처럼 크리스마스를 앞두고 뭔가가 이상하고 혼란스러웠지만 다행히 1주일만에 망상도 사라졌 다고 여동생 빌에게 편지를 썼다. 다섯번째 위기는 생레미병 원에서의 1890 년 1월 21일부터 1주간이다. 동생 빌에게 보낸 편지에서는 예견할 만한 내용은 전혀 없었다. 주치의는 아를 에 갔다 온 이튿날부터 발작이 1주간 있었다고 테오에게 보 고하였다. 여섯번째 위기는 생레미병원에서의 1890년 2월 23일부터 65일간이다. 역시 아를 방문 이후의 일이다. 2월 24일 주치의는 아를 방문 중 증상이 재발한 빈센트를 병원으 로 데려오게 한다. 금방 좋아졌다가 갑자기 우울해져 묻는 말에도 전혀 반응을 하지 않았다. 빈센트는 2달간 편지를 쓰 지 않았고 온 편지도 읽지 않았다. 5월 16일 회복된 빈센트는 혼자서 병원을 떠나 파리 테오 집에 잠시 머물고, 이어 오베르 의 정신과의사 가셰에게로 간다. 2 달 반 동안 정신적 위기상황 을 보이지 않던 빈센트는 7월 말 갑자기 자살로 생을 마감한다.

이중섭은 1955년 7월부터 대구성가병원, 9월초 수도육군 병원, 9월말 성베드로병원으로 이어지는 6개월간의 정신병 원생활을 한 후에 12월 말 퇴원하였다. 퇴원 후 화가 한묵, 박고석, 시인 조영암, 소설가 박연희와 더불어 정릉에서 예 술가들과 기거하며 작품활동을 하였다. 명동으로 출타할 정 도로 건강이 호전되었으나 음주로 인해 건강이 악화되고 멍 한 상태에서 거식증까지 보여 7월초 청량리 무료병동에 입 원 후 간질환이 심각하여 7월말 적십자병원 내과로 전원가 게 된다. 즉 4곳의 정신병원에 입원하였으나 남겨진 병록지 기록들은 별로 없다. 전해오는 주변인들의 진술, 성베드로병 원에서 그린 낙서화를 통해 입원 시 보인 정신증상을 정리해 보면 다음과 같다. 주변인 진술이라 증상 발생의 시기적 오류 나 과장 내지 허구적 신화가 있을 경우 2014년 출판된 최열 의 〈이중섭평전〉을 우선적으로 참조하였다.

발병하여 입원치료하는 과정에서 일관되게 이중섭이 보이 는 가장 중요한 정신병리는 과도한 양심(초자아, superego),
모든 잘못된 결과를 자신의 탓으로 돌리는 병적 죄책감, 죄를 지었으니 마땅히 처벌을 받아야 된다는 피해망상과 처벌 공 포, 음식을 거부하는 거식증, 자신이 지은 죄를 보상하려는 과잉보상행동이다. 이를 좀 더 자세히 살펴보면 아래와 같다.

\section{피해망상(처벌망상)}

정신병원에 입원하게 된 결정적 사유는 자신을 빨갱이로 몰아 처벌하려 한다는 피해망상 혹은 처벌망상으로 인해 반 복적으로 경찰서를 찾아가 자신이 빨갱이가 아님을 주장하 는 행동이었다. 피해망상의 배경에는 나름대로의 이유가 있 다. 월남전 공산주의 체제하에서 원산미술동맹부위원장 경 력으로 인해 월남 후에는 신상 조사 과정에서 순탄치 않았 으며, 1953년 5월 부산 국립박물관 화랑에서 열린 신사실파 전에〈굴뚝1〉, 〈굴뚝2〉를 출품하였는데 이중섭을 포함한 출 품화가들을 정보기관에 데려가 사상검증을 한적이 있으며, 은지화가 외설스럽다며 철거 명령이 떨어진 경험이 영향을 주었으리라고 본다. "너 빨갱이지, 왜 8.15때 안 내려오고, 6.25때 내려왔냐?”라는 이기련의 잦은 농담이 결정적 계기 가 된다. 이중섭은 그림에 빨간 색을 쓰는데 심리적으로 주 저함을 느낀 것으로 보인다. 이대원의 증언에 의하면(Choi 2014) 모테(Mottet)의 강렬한 주황색 화집을 보고 감탄하는 것을 보고 이중섭은 색을 굉장히 절제하고 있다는 걸 알 수 있다고 하였다. 실제 발병 후 이중섭의 작품에서는 붉은 색 이 줄어들고 흰색이 늘어난 것을 관찰해 볼 수 있다. 성가병 원 입원 시 흰색 물감을 밤새 쓰고는 없어졌다고 구석구석 찾아 헤맨적이 있다. 이중섭의 피해망상 기저에는 한국전쟁 이라는 외부적 요인으로 인한 사상검열에 대한 피해사고와, 개인 욕심을 채우려 예술을 한답시고 세상을 속인 죄로 인해 처벌을 받을지 모른다는 공포가 깔려 있다. 이를 정신역동 관 점에서 살펴보면 아버지 부재 때문에 오이디푸스 콤플렉스 를 원만히 해결하지 못한 이중섭의 취약성이 극한 상황에서 노출되었다고 볼 수 있다. 즉 사상검열이 이중섭에게는 외부 에서 가해지는 거세불안으로 작용했을 가능성이 높다(Sohn 2016). 이에 더하여 막대한 금전적 피해를 준 오산고 후배 마 씨, 그림을 훔쳐가고 작품료를 술값으로 써버리게 만드는 예 술인들, 이중섭이 일본으로 가는 것에 대해 소극적이었던 부 인과 같은 주변인들과 세상에 대한 분노가 공존 하였으리라 본다. 이중섭의 경우 빈센트와 달리 피해망상을 유발하는 환 청에 대해서는 알려진바 없다.

\section{죄책망상과 이에 따른 거식, 거부, 자학, 보상행동}

"내가 동경에 그림 그리러 간다는 건 거짓말이었어. 남덕 이와 아이들이 보고 싶어서 그랬지.", "이 세상에 면목이 없어. 
나는 세상을 속였다. 예술을 한답시고 공밥만 얻어먹으면서 놀았다.”고 대구성가병원에 입원한 날부터 이런 말을 하며 음식을 거부하였다. “나는 쓰레기야 살 자격이 없어.”라며 속 죄하는 듯한 음식거부는 정신적 고비 때마다 등장하고 심할 때는 수액주사 마저 거부하여 고무호스를 통해 강제로 음식 을 투입하거나 전기경련치료를 실시하게 된 계기가 되었다. 거식증과 유사한 증상 중의 하나가 부인이 보낸 편지를 읽 지 않는 편지 거부증이다. 가족을 만나려는 개인적 욕망이 죄인 양 부인의 편지를 읽는 것 또한 죄로 간주하여 자신과 가족의 안전을 위해 편지를 읽지도 쓰지도 않은 것인지, 아 니면 가족을 위해 아무것도 할 수 없는 상황에서 편지를 읽 어본 들, 편지를 써본 들 소용이 없다는 절망감에서인지, 혹 은 자신의 일본 귀국에 소극적인 부인과 장모에 대한 분노 가 내포된 행동인지 살펴보아야 한다. 거식이나 거부가 수동 적 행동이라면 보다 적극적인 자기징벌은 자신의 신체에 위 해를 가하는 자학행동이다.

자신을 학대하고 괴롭게 만들어 죄값을 치루겠다는 의도 로 머리를 박박 깎고 자기 손등을 비벼서 피를 내는 신체적 인 자학증을 보였다. 한편 그 이유를 물으면 "남덕이 미워서, 남덕이 죽일려고.”라고 중얼거리고, 조카가 병문안 왔을 때 “화가 시인은 거지같은 녀석들이니 다 죽여야 한다.”라며 가 학적인 말을 하였다. 이는 거식-거부-자학행동 이면에는 우 울, 절망, 죄책감 이외에 타인에 대한 분노가 내면에 존재한 다는 것이다. 극단적인 자학행동은 자살인데 이중섭의 경우 에는 자살시도에 관해 특별히 알려진 것은 없다. 입원 전부 터 보였던 죄책감에 대한 보상행동은 입원 후에도 여전히 보였다. 병원 복도와 계단을 말끔히 쓸고 닦았고, 간호사를 오히려 위로하고, 가톨릭 신자가 되어 새사람이 되겠다고 하 였다. 마지막 보인 보상행동은 건강이 극도로 악화되어 적십 자병원으로 전원 갈 때, 각방을 돌면서 일일이 환자들에게 인사를 하고 받은 성경책 값과 슬리퍼 값을 지불하고야 안 심하고 병원을 떠났다는 일화이다.

두 화가가 느낀 병실생활과 자신의 정신병에 대한 인식을 비교하면 다음과 같다. 빈센트의 경우에는 환청, 피해망상, 우울증으로 인한 고통이 주기적 발작 형태로 심하게 자신을 괴롭혔기 때문에, 대체로 자신의 병을 인정하고 치료에 저항 없이 병실생활에 협조적이었다. 반면 이중섭의 경우에는 양가 적 이었다. 발병 초기인 1955년 대구에 최태응과 같이 생활할 때 "정신병에 해골을 삶아 먹으면 특효인데 넌 종군기자이니까 쉽게 해골을 구할 수 있지 않느냐?”라고 부탁한 사실(Kang 1999)은 정신병을 인정한 듯 보이지만, 1955년 8월 이종 사촌 이광석과 친구 김이석이 대구성가병원에 입원한 이중섭을 퇴원시켜 서울로 데려갈 때 배웅나온 최태응 귀에다가 "이
새끼들 날 서울로 잡아가려고 왔다. 난 왜관쯤 가서 도망쳐 올거야.”라고 하였다(Jo 1971). 외출 시 귀원을 하지 않아 경 찰에 신고된 적도 있으며, 간호원 몰래 병원을 탈출하여 명동 일대를 헤매다가 혜화동에 있는 한묵의 집으로 찾아와 하룻 밤 재운 뒤 잘 달래서 다시 병원에 데려다 준 적도 있었다. 1955년 12월 중순 퇴원을 1주일 앞둔 시점에서 부인에게 쓴 편지에는 "모든 사람들 덕분에 완전히 건강을 되찾았습니다. 동경에 가는 것은 병 때문에 어려워졌소. 당신과 아이들이 오는 방법을 모색해 봅시다.”라는 식으로 자신의 병과 현실 을 냉정하게 인정하는 태도를 취하였다.

\section{편지를 통해 얻을 수 있는 자료들}

두 화가의 질병 연구에 있어 가장 객관적인 정보는 남겨진 편지다. 저자는 빈센트가 1889년 1월 22일부터 1890년 6월 4일까지 테오에게 보내는 13통의 편지에 기록한 자신이 체 험한 정신증상, 병식, 주치의에 대한 생각을 소개한 바 있다 (Lee 2021). 빈센트는 자신의 정신질환은 뇌에 문제가 있는 간질이라고 알고 있었으며 신체적 질환과 차이가 없다고 인 식하였다. 약물치료 효과를 인정하였고 주치의에 대한 신뢰 감이 높아 치료 전반에 매우 협조적이었다. 다음 발작 시점 을 예측하여 생레미병원을 퇴원 후 혼자 파리로 이동 가능 한 시점까지 의사와 상의할 정도로 자신의 질병에 대해 잘 알고 있었음을 편지를 통해 알 수 있었다.

이중섭의 경우 1952년 7월 가족과 헤어진 후 편지 왕래가 시작되었지만 현재 세상에 알려진 첫 편지는 1953년 3월 9일 이다. 부인에게 보낸 편지가 39통이며 아이들에게 보낸 20여 통을 합하면 약 60 통이다. 부인에게 보낸 편지를 시기별로 나누어 보면 이중섭이 1953년 7월 일본 방문 전에 12편, 방 문 후가 3편, 통영시절 2편, 남도에서 상경하여 개인전 준비 에 열중하던 기간(1954년 6월-1955년 1월)이 20여통으로 가 장 많다. 이 기간은 창작열에 불탔거나 경조증 시기로 판단 된다. 한편 편지 쓰기를 중단한 시기를 살펴보는 것 또한 의 미가 있다. 1955년 2월 22일 서울 개인전을 마치고 대구로 출발 전에 편지를 쓴 후 10 개월간 침묵하다 성베드로병원에 서 퇴원 1주일을 앞둔 1955년 12월 중순에야 비로서 생의 마 지막 편지를 부인에게 썼다. 이후 사망까지 10 개월간 부인의 편지도 읽지 않고 답장 또한 하지 않았다. 빈센트나 이중섭 모두 기분 상승기에는 편지 분량도 늘어나고 편지 보내는 횟 수도 늘어나지만 정신적 혼돈기나 우울기에는 편지를 쓰지 않았다.

빈센트는 편지에 자신이 체험한 정신증상, 병식, 병에 대 한 걱정, 주치의에 대한 생각을 자세히 썼지만, 이중섭은 입 원기간 중 단 1통의 편지를 퇴원 1주전인 1955년 12월 중순 
부인에게 간단히 썼다. "대구 서울 친구들의 정성어린 성원 에 힘입어 이제 건강을 되찾아서 1 주일이면 퇴원한다오... 너무 그대를 만나고 싶어 무리한 탓이오. 남덕씨에게 아이 둘을 맡기고 고생시켜 미안하오. 부족한 나를 이해해 주오. 이제는 그림도 그리고 씩씩하게 생활하니 기뼈해 주오. 며칠 뒤 아이들에게 그림을 그려 보낼 생각이오. 몸이 아프다보니 도쿄에 가는 것도 여의치 않게 되었어요. 도쿄에서 당신이 오 는 방법과 내가 가는 방법.. 잘 조사해보고 다시 연락하리 라.” 이 편지 내용을 보면 치료가 성공적으로 되어 병식도 생 기고 현실판단력이 회복되었음을 알 수 있다.

부인에게 보내는 대부분의 편지에는 사랑의 불변함을 연 애편지 쓰듯 표현하였고, 현 상황이 자신의 무능으로 인해 힘들지만 함께 참고 견디어내자는 위로, 격려의 내용이 대부 분이다. 하지만 간혹 질책성 분노를 표현한다던지, 지나친 자신만만함, 의욕충만함, 과장법을 사용한 과도한 감정을 기 술한 편지도 있다. 우울증 환자에서 양극성장애를 배제하기 위한 감정기복에 관한 정보가 필요하다. 손성은은 이중섭의 편지내용 분석과 동시기의 행동의 예를 들어 이중섭의 기분 상태를 분석하였다(Sohn 2016). 전혁림이 실수로 이중섭만 빼 고 지인들과 회식자리를 가진 것에 평소와 달리 격한 분노를 보였다는 점을 연결시키며 우울증에서 조증으로의 반동현상 임을 보고하였다. 1954년은 이중섭에게, 1955년 1월 개인전을 앞두고 창작열이 최고조에 이른 시기로 작품제작 및 부인에 게 편지발송 횟수도 총 38 편중 20 편에 이르는 가장 많았던 해 이다. 저자는 입원 전 경조증 에피소드라 할 수 있는 1954년 새해 편지와 11월 편지들을 소개하면 다음과 같다.

통영에서의 새해 첫 편지인 1954년 1월 7일 편지는 과거 의 이중섭의 착한 ‘소' 이미지의 편지와는 다르다. 이제는 막 다른 골목에 다다라 무슨 수를 쓰더라도 일본에 가서 가족과 합쳐 돼지처럼 천한 일도 마다하지 않고 악착같이 살아보겠 다는 결연한 의지를 표현하였다. 이는 이중섭의 일본행을 주 저하는 부인과 장모에 대해 분노하고 질책하는 도전장이기 도 하다. '피투성이가 되어 외치는 마음 속 절규’라는 말도 섬 뜩하고, '선량한 우리 네 가족은 세상에 소용없는 하나 둘 정 도 죽여서라도 살아가야 한다.'는 잔인한 말까지도 적고 있 다. 후반부에는 '참기 힘든 괴로움 가운데서도 믿을 수 없을 만큼 강렬하게 욕구가 일어나 작품을 마구 그려대고', ‘자신 감이 넘치고 넘쳐 터질 것만 같다', '밤 10 시 넘도록 제작에 몰두하고', '친구들이 내 제작에 놀라 눈을 둥그렇게 뜬다'고 표현하고 있다. 1 월 7일 편지는 장문의 편지로 우울증의 반 동작용으로 인한 경조증, 조증으로의 이행을 의심하게 하는 편지라 할 수 있다.

좀더 명확한 경조증, 조증 상태는 개인전을 열어 작품을
판돈으로 일본으로 가서 가족과 함께 살겠다는 강렬한 포부 로 7월부터 개인전을 맹렬히 준비했던 막바지 시기인 54년 11월경이다. 1954년 10월 중순 편지에는 "하루 종일 얼굴도 못 씻는 날이 며칠이고 계속되고 요즘와서 제작의 컨디션이 점점 좋아지고 있고 목숨을 걸었다.”고 적었다. 10월 28일 편지에는 "자신이 세상에서 가장 뛰어난 새로운 표현자이고 정직한 화가라는 사실을 믿어달라.”라고 썼다. 11월 어느 날 쓴 편지에는 "나도 놀랄 정도로 작품이 잘되어 감격스러워 터질 것 같다. 이른 새벽에 일어나 전등을 밝히고 그림을 제 작하고 있다."고 적었다. 1954년 11월 중순의 편지에서는 "머 릿속과 눈이 차츰 더 맑아져서 자신이 넘치고 넘쳐서 번쩍번 쩍 빛나는 머리와 안광으로 제작, 제작-표현 또 표현을 계속 하고 있다.”고 적었다. 이는 과다한 표현과 단어를 2번씩 반 복하는 조증 환자들에서 흔히 보는 증상들이다. 1954년 11월 21일 편지에는 "싸늘하고 외로운 한밤중에 빼에 스미는 고독 속에서 혼자 텅 빈 마음으로 있다. 그림도 손에 잡히지 않아... 휘파람 노래를 부르고 시집을 뒤적인다. 정말 외롭구려. SOS-SOS-SOS- 빨리 힘을 내게 편지를 보내달라."고 적었 다. 이는 감정기복이 심한 힘든 상황이었음을 알 수 있다. 1954년 11월 말 편지에는 "밤낮을 가리지 않고 정신없이 그 림을 그린다오. 너무 바빠서 몇 일이나 세수를 못했는지 모 른다오. 요즘 들어 아주 그림이 잘 그려진다오. 엄청난 대작 이 만들어질 것이오. 생각만해도 가슴이 부풀어 올라 하늘을 날아갈 기분이오."라고 적었다.

저자가 보기에는 상기 편지들을 썼던 동시기에 이중섭에 게서 손성은이 지적한, 평소와 달리 지인으로부터 초대받지 못한 분노를 표출하는 등 몇몇 단편적인 문제행동들이 있었 으나 광범위하고 뚜렷한 조증 행동장애들을 보이지는 않았 던 바 조증 보다는 경조증 상태라 여겨지지만, 예술가들의 창작열에 불탄 긍정적 시기로 보는 관점도 염두에 두어야 할 것 같다(Sohn 2016).

\section{진 단}

1890년 빈센트 사망 후 150 명 이상의 의사들이 그의 사인 과 그가 않았던 질병에 관해 30 개 이상의 진단을 제기하였 으나 현재 확증된 것은 없다(Blumer 2002). 진단 주장 근거 자료는 (1) 병록지, (2) 편지(빈센트-테오, 빈센트-지인, 주치 의-테오), (3) 가족력, (4) 주변인 진술, (5) 작품 분석이다. 1956년 사망한 이중섭의 경우 빈센트와 비교하면 병록지 자 료는 미미하고, 이중섭이 부인에게 보낸 편지들이 38통 있으 나 실제 투병기간에 보낸 편지는 정신병원 퇴원 1 주일전에 작성한 단 1 편뿐이어서 빈센트와 달리 이중섭 자신이 기술 한 정신증상, 병식, 주치의와의 관계를 파악하기 어렵다. 가 
족병력 역시 빈센트의 경우 6남매중 4명이 정신병력이 있으 나, 이중섭의 경우 부친이 30세 나이에 천정만 딿어지게 쳐 다보다가 사망하였다는 고은 평전(Go 2004)의 주장이 유일 하여 확증이 어렵다. 다만 이중섭의 경우 객관적 진단이 빈 센트보다 용이한 점은 평상시 잘 적응하다 누구나 공감할 만한 외부 환경적 스트레스(전쟁, 분단, 가족과 이별, 경제적 위기)로 인해 생의 말년에 단기간 발병하였던 바, 빈센트와 달리 생의 전반에 걸친 성격장애와 대인관계 갈등문제는 없 었고, 이중섭은 친한 주변 지인들(시인, 소설가, 화가)의 증 언이 넘쳐나 신화와 허구를 구별해야 할 정도로 자료가 풍 부하고, 정신과 병동에서 그린 낙서화를 비롯하여 어릴 적부 터 평생 그린 〈소〉와 같은 연대순 작품 비교분석 자료가 충 분하다는 점이다. 빈센트의 진단은 측두엽 간질, 양극성장애 (정동장애, 조현정동장애), 조현병, 경계성인격장애, 간헐적 급성 포르피리아, 메니에르병, 안과 질환, 압생트-알코올 남 용, 만성적 독성, 뇌병변장애, 납중독, 영양실조와 탈진 등이 현재 제기되고 있는데, 이에 대한 보다 자세한 정리는 저자 의 글을 참고하길 바란다(Lee 2021). 상기 진단 중 본고에서 는 빈센트와 이중섭이 공유하였다고 추정되는 진단에 국한 시켜 살펴보고자 한다.

첫번째 진단은 양극성 정동장애 혹은 조현정동장애이다. 이중섭의 진단에 관해서 주치의 유석진은 구체적 언급은 없 지만 당시의 진단 개념으로 볼 때 조현병으로 보았을 가능 성이 가장 높다. 이부영이 발표한 '이중섭 회화에서 본 그리 움의 의미-위기와 창조성과의 관련'에 따르면 이중섭의 정 신착란은 조현병의 긴장성혼미(catatonic stupor)일수도 있 겠으나 주요우울장애의 우울성 혼미(depressive stupor), 혹 은 조현정동장애(schizoaffective disorder)로 볼 수 있다고 하였다(Lee 1994).

이중섭이 입원 당시 피해망상 등의 정신병적인 모습을 보 인 것이 사실이지만 조현병으로 보기에는 몇 가지 문제점이 있다. 사회적으로 잘 기능하던 사람이 갑자기 외부스트레스 로 인해 나이 40 세에 헛소리를 시작하였고, 퇴원 1주전 아내 에게 보낸 편지를 살펴보면 병식과 현실감이 돌아왔고, 퇴원 후 인격의 와해나 퇴행없이 한동안 창작과 사회활동에서 적 절한 모습을 보여줄 정도로 회복되었으며, 핵심 정신병리가 문제를 외부 탓으로 돌리는 것이 아니고 자기비하 자책 죄 책망상이라는 점은 조현병보다는 정신증을 동반한 우울병 에 가깝다고 본다.

2000년대 들어 임상의들의 관심은 우울장애 환자의 과거 력에 양극성장애 진단이 가능한 조증(1주 이상의 기분상승), 특히 경조증(4일 이상의 기분상승) 삽화가 있었는가이다. 기 분변동 삽화 존재 여부에 따라 진단이 달라지기 때문이다.
이중섭의 경우 1952년 7월 가족을 일본으로 보내고 그 해 겨 울에 의욕상실 자기능력비하 등 명백한 우울증 시기가 있었 고, 이후 1955년 대구성가병원 입원 전 자주 혼자 우는 광경 이 목격되었고, 1956년 청량리병원 입원 전 사람이 찾아와 도 만나지 않고 컴컴한 방에 멍하니 하루 종일 천정만 바라 보았다는 주변인들의 증언을 보면, 명백한 우울증 에피소드 가 여러 번 있었다고 보여진다. 한편 경조증 삽화는 본고의 ‘편지에서 얻을 수 있는 자료들’에서 앞서 언급한대로 1954 년 봄, 특히 가을에 있었다고 추정된다. 이러한 점들을 고려 할 때 손성은(Sohn 2016)은 p.189-190에서 이중섭의 1955년 입원 당시의 상태를 정신증을 동반한 양극성정동장애로 진 단해 볼 수 있다고 하였다. 저자 역시 명백한 조증 삽화보다 는 경조증 삽화 존재에 동의하는 바 이중섭의 진단을 양극 성정동장애 II형이라고 추정한다.

빈센트의 진단을 조현병이라고 하였던 당대의 유명한 정 신병리학자인 Jaspers의 주장(Jaspers 1926)은 더 이상 설득 력이 없으며 이중섭 역시 조현병이라는 진단에는 회의적이 다. 두 화가의 공통점은 명백한 우울삽화와 더불어 과잉활동 양상으로 나타나는 경조증 삽화가 존재하였고, 후유증 없이 회복되는 점을 감안하면 양극성장애 II형 진단이 가능하다 는 것이다. 차이점은 빈센트의 경우 상대적으로 이중섭보다 환청, 피해망상으로 인한 자살 자해 증상이 심하였던 바, 양 극형 조현정동장애 진단에 더 무게가 실린다고 보여진다.

두번째 진단은 물질남용장애이다. 빈센트의 경우 압생트/ 알코올, 니코틴, 커피, 유기용매제 남용자이며 이중섭은 알 코올 니코틴 남용자이다. 압생트가 빈센트의 정신 증상에 영 향을 주었다는 사실은 명백함으로 진단과 관계없이 모든 연 구자가 동의하는 사실이다(Arnold 1992). 생레미병원에서 4 번의 정신발작 중 3 번이 아를을 다녀온 후 발생하였는데 이는 음주와 연관성이 높다.

이중섭의 간질환, 정신 상태 악화, 그리고 사망에는 '술’이 라는 요인이 있다. 고은(Go 2004)에 의하면 가족들이 일본 으로 돌아간 1952년 7월 이후는 특히나 술 친구들과 술자리 가 많았다. 자주 술 친구들과 어울렸고 점차 술 자리마다 모 르는 사람과 말다툼을 하고 얻어맞는 알코올행동장애가 종 종 발생하였다(Choi 2014). 퇴원 후의 이중섭은 심한 정신증 은 사라졌지만 우울감과 외로움에 술에 의존하였으며 이를 통제할 주변인들은 거의 없었다. 알코올의존이 심해지면 위 염이나 급성 췌장염, 간염, 간경화 등의 신체 건강악화의 위 험성이 높아진다. 이중섭의 사인이 된 간질환은 바로 알코올 의존의 결과였다.

이 밖에 두 화가 모두의 정신적 신체적문제 악화 요인은 알코올 의존으로 인한 영양결핍이다. 빈센트의 경우 술로 인 
한 부실한 식사, 파이프 담배 때문에 생긴 불량 치아로 인한 치통, 술 커피에 의한 위장장애가 영양결핍을 초래하였고, 이중섭의 경우는 이에 더하여 간질환, 거식증으로 인한 영양 결핍이 더 큰 문제가 되었다. 특히 비타민 $\mathrm{B}$ 복합체의 결핍 은 두 화가의 정신 증상 유발 혹은 악화에 영향을 주었으리 라 여겨진다.

\section{두 화가의 정신역동}

빈센트의 형은 빈센트가 태어나기 1년전 같은 날짜에 사 산된채로 출생한다. 1 년후 출생한 빈센트는 부모의 뜻에 따 라 죽은 형의 이름, 교회 등록번호를 그대로 물려받게 된다. 또한 성장기 빈센트는 교회 주변에 매장된 형의 묘비를 자주 접하였다고 한다. 이러한 사실들은 빈센트의 정신역동에 핵 심 키워드로 자주 등장하는 교체(replacement), 이중성(double)의 근거가 된다(Meissner 1994; Blum 2009).

교체란 죽은 자를 대신하여 재탄생하고, 환생하고, 부활하 였다는 죽은 자 중심의 의미를 담고 있으며, 이중성이란 한 개체에 죽은 자와 산 자가 동시에 존재한다는 의미로 분리정 체성(split identity), 이중정체성(double identity), 위정체성 (pseudo-identity), 허위자기(false self) 형성을 의미한다(Cain 과 Cain 1964). 교체된 아이, 즉 빈센트의 측면에서 살펴보면 태어남과 동시에 죽음, 환생, 부활, 영원함에 대한 개념이 이 른 나이에 시작되고, 부모 사랑에 대한 욕망을 죽은 형의 망 령과 경쟁해야 하며, 교체된 아이로서 부모를 위로하고, 죽은 형의 몫까지 대신하려는 성취욕, 살아남은 자로서의 승리감 과 동시에 죽음에 대한 공포가 컸다고 추측된다(Blum 2009).

교체된 아이를 둔 빈센트 부모 입장에서 살펴보면, 죽은 첫 아들에 대한 우울증을 필두로 한 애도반응과 더불어 교 체된 아이에 대한 기대감, 실망감이 빈센트의 성장에 영향을 주었으리라 본다. 빈센트의 교체와 이중성은 그의 작품과 대 인관계를 통해 엿볼 수 있다. 평생 40여점이 넘는 자화상은 빈센트의 이중 정체성 갈등을 해결하려는 작업이었고, 빈센 트의 주요 그림 소재인 사이프러스, 대지, 땅, 별, 하늘은 죽 음, 부활, 영원을 상징하는 것이다. 유년기 시절 죽은 형이 이중성의 대상이었다면 살아있는 대상으로는 테오가 떠오 른다. 테오의 약혼, 결혼, 조카 출생으로 테오와의 공생관계 가 무너질 위기상황에서 빈센트의 정신증상이 악화되고 극 단적 행동을 하게 된다. 마지막 이중성의 대상은 빈센트와 이름이 똑같은 조카이다. 죽은 형과 마찬가지로 빈센트에게 조카는 경쟁상대 혹은 위협적인 존재로 느꼈을 가능성이 높 다(Meissner 1994).

이중섭의 경우 핵심 정신역동은 만 2세 이전의 아버지 사 망으로부터 출발한다. 구강기 시절 형성된 어머니에 대한 과
도애착, 유아기적 구강욕구는 초등학교 입학하느라 집을 떠 나는 7살 때 젖떼기가 이루어졌고, 초 4까지 집에 오면 엄마 젖을 찾았다고 한다. 성년이 되어서 과도한 구강욕구는 담 배, 파이프에 집착하는 행동으로 이어진다. 아버지를 대신할 인물로는 11 세 위의 큰형이 있으나 어린시절 같이 지낸 기 간이 거의 없으며, 초등학교 평양시절 외조부를 만나기 전까 지 아버지상은 없다. 아버지의 부재는 남근기의 건전한 오이 디푸스 콤플렉스 해결을 미완성으로 남길 수 밖에 없다. 아 버지 부재로 문제해결 없이 왕의 자리에 너무 쉽게 오른 이 중섭은 과도한 자신감을 갖거나, 제거된 아버지의 귀환이나 다가올 복수가 두려울 수 밖에 없었다. 고생도 해보고 문제 도 해결해 보아야 면역력도 생기는 이치와 같다. 이중섭의 미해결 오이디푸스 콤플렉스는 남성상 과시, 거세불안, 성애 착물로 상징화되어 작품에 표현되거나 정신증상으로 일상 생활에 노출되게 된다(Sohn 2016).

남성상을 표현하는 작품 〈게와 생선에 낀 아이〉에서는 거 세자인 게를 밟고 남성을 상징하는 물고기를 트로피처럼 치 켜든 아이를 그렸다. 거세공포를 표현한 성기를 물려는 게와 칼을 그린 작품으로는〈게에게 물린 동자〉, 〈칼과 숫돌이 있 는 안방〉, 〈소를 괴롭히는 새와 게〉가 있다. 성적욕구의 분 출을 표현하는 작품으로는 여성을 상징하는 개구리에게 소 변을 퍼붓는 아이를 그린 〈오줌싸게와 닭과 개구리〉, 여성 의 엉덩이와 성기를 그린 〈두개의 복숭아〉, 이외에 짝짓기 를 하는 새, 닭, 나비-꽃 그림들이 있다. 일상생활에 노출된 거세공포 행동으로는 “하도 쓰지 않아서 썩어버리면 어쩌 나" 하고 성기에 소금을 뿌리는 행위를 생각해볼 수 있으며, 여성 성기를 떠올리는 동그란 물체만 보면 성적 욕구가 올 라와 도망치는 원형강박증은 자발적 거세에 속한다. 부인을 지칭할 때 '발가락군' 혹은 음핵을 떠올리게 하는 '아스파라 거스란 칭호는 자연스러운 이중섭의 성적욕구 분출의 방법 일 수 있었겠다.

두 화가의 화풍이나 그림 소재가 달라 공통점을 찾기란 쉽지 않다. 어린시절로 회귀하여 어머니에 대한 그리움이란 주제를 공통점으로 찾는다면 다음과 같다. 먼저 빈센트의 작 품을 소개한다면 〈에텐의 추억> (Figure 2)이 떠오른다. 이 그림은 고갱과 함께 거주하던 1888년 11월의 작품이다. 빈센 트는 테오를 비롯한 가족을 대상으로 그린 작품이 이 그림 이외에는 없으며, 평소 어머니에 대한 언급이 거의 없으며, 항시 사물을 직접보고 그 느낌을 그리는 화가이다. 고갱의 권 유대로 어린시절 고향의 추억을 회상하였고, 어머니와 막내 여동생 빌을 등장시켜 어머니에 대한 그리움을 표현하였다 는 점에서 볼 때 이 그림은 빈센트의 그림 중 매우 특이하고 유일하다. 


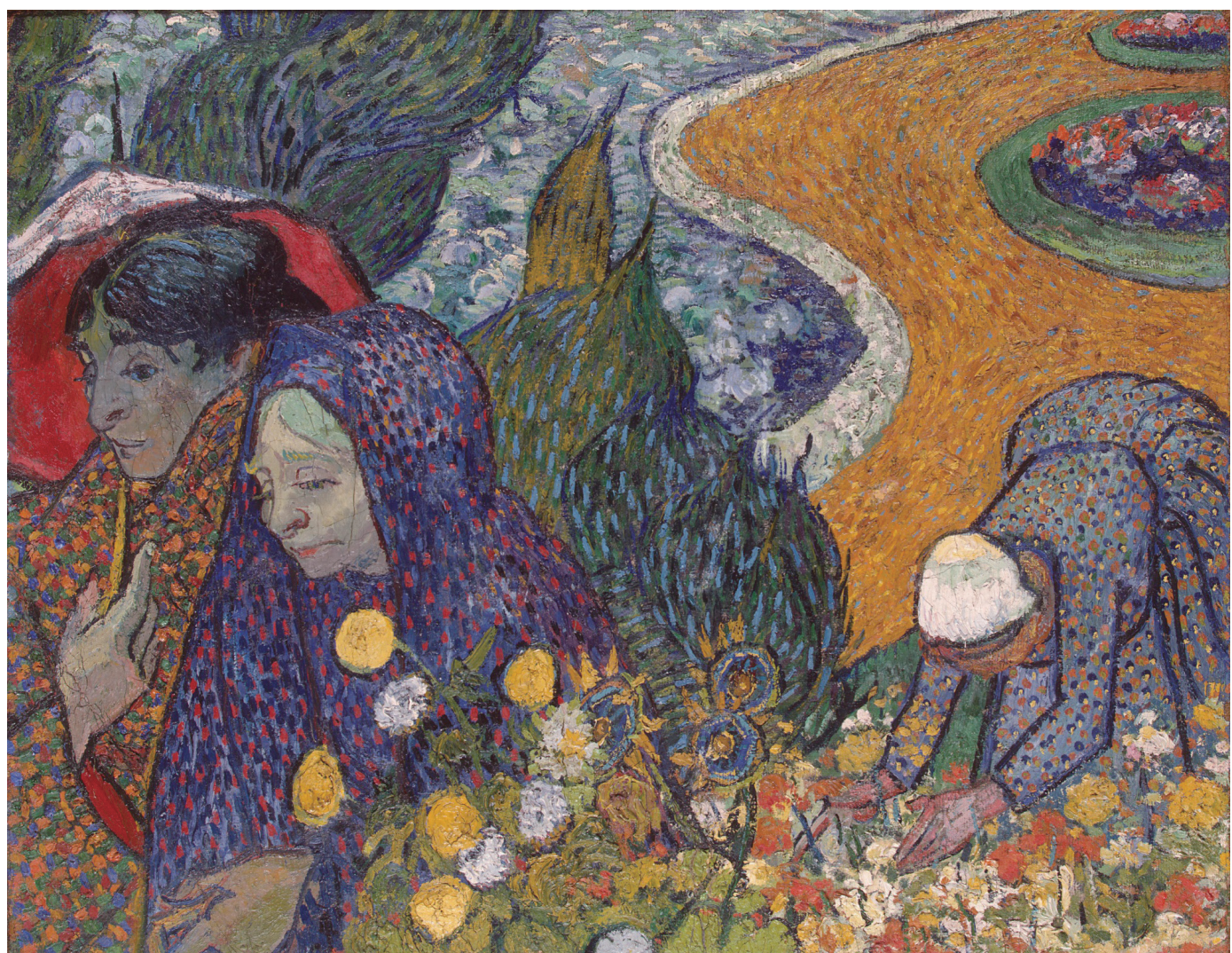

Figure 2. Vincent van Gogh, <Memory of the Garden at Etten>, 1888 , Oil on canvas, $73 \times 92 \mathrm{~cm}$, St Petersburg, The State Hermitage Museum.

이중섭의 작품으로는 사망 6개월 전인 1956년 3월 정릉에 서 그린 〈돌아오지 않는 강〉이 있다(Figure 3). 일본행 좌절 로 낙담하여 부인이 보낸 편지마저 보기를 거부한 채 이북 에 남겨져 만날 수 없는 어머니를 그리며 창가에서 멍하니 기다리는 심정을 표현한 작품이다.

\section{주치의와의 관계 및 치료방법}

빈센트 치료에 관여한 의사는 아를병원 주치의 레이(Felix Rey), 생레미 정신병원의 페이롱(Théophile Peyron), 오베르 의 가셰 3 명이다. 아를병원의 레이는 빈센트를 잠재성 혹은 가면성 간질이라 판단하고 성심껏 치료했으며 병원 밖에서 도 임시 거처를 제공하는 등 여러 편의를 제공하였다. 생레 미 정신병원에서 1 년 넘게 빈센트 담당 의사였던 페이롱은 은퇴를 앞둔 안과 전문의로 약물투여는 하지 않았던 것으로 판단된다. 오베르에서 퇴원한 빈센트를 담당한 가셰(18281909)는 빈센트의 병세를 심각하게 보지 않고, 휴양하면서 그림 작업을 하고 자신이 대화 상대가 되어주면 곧 치료되 리라 생각했다. 따라 빈센트의 작품활동을 돕고 관심을 두는 보호자의 역할을 하였다. 빈센트 역시 가셰의 치료에 대한 큰 기대를 걸지는 않았다.
이중섭이 만난 정신과 의사는 4 명이다. 김준명은 대구 달 성공원 근처 개원 정신과 의사로 1995년 이중섭과 여관에 동 거중이던 최태응의 요청에 의해 여관을 방문하여 은밀히 이 중섭의 정신상태를 파악하였다고 알려져 있지만(Go 2004) 더 이상의 정보는 없다. 대구성가병원 주치의에 대해서도 어 떠한 이유에서인지 알려진 것이 없다. 수도육군병원과 성베 드로병원에서 4개월간의 주치의는 유석진이었다. 청량리뇌 병원 담당의 전병린은 "이 사람은 정신은 멀쩡합니다. 정신 과가 아니라 내과 대상입니다.”라며 적십자병원으로의 전원 을 시행하였다. 따라서 정신과적 치료에 관여한 의사로 알려 진 사람은 유석진이 유일하다. 유석진(1920-2008)은 1982년 한국임상예술학회 초대 회장을 지냈고 음악, 영화, 연극, 그 림 등 예술을 환자 치료에 접목하는 데 앞장서 현재 정신질 환 치료에 널리 쓰이고 있는 '사이코 드라마'와 ‘음악 요법' 태 동에 관여하였고, 정신과 환자들을 시장이나 음식점, 극장 등 으로 데리고 나가 치료하는 '사회현장 치료법'을 시도하였다. 일 예로 1955년 12월 성베드로병원 입원 당시 이중섭은 유석 진 원장과 함께 동행 외출 형식으로 이중섭이 일본 유학시절 부터 친하게 지낸 성북동의 김환기 화백집에 간 적이 있다.

이중섭이 입원한 성가병원, 수도육군병원, 성베드로병원, 


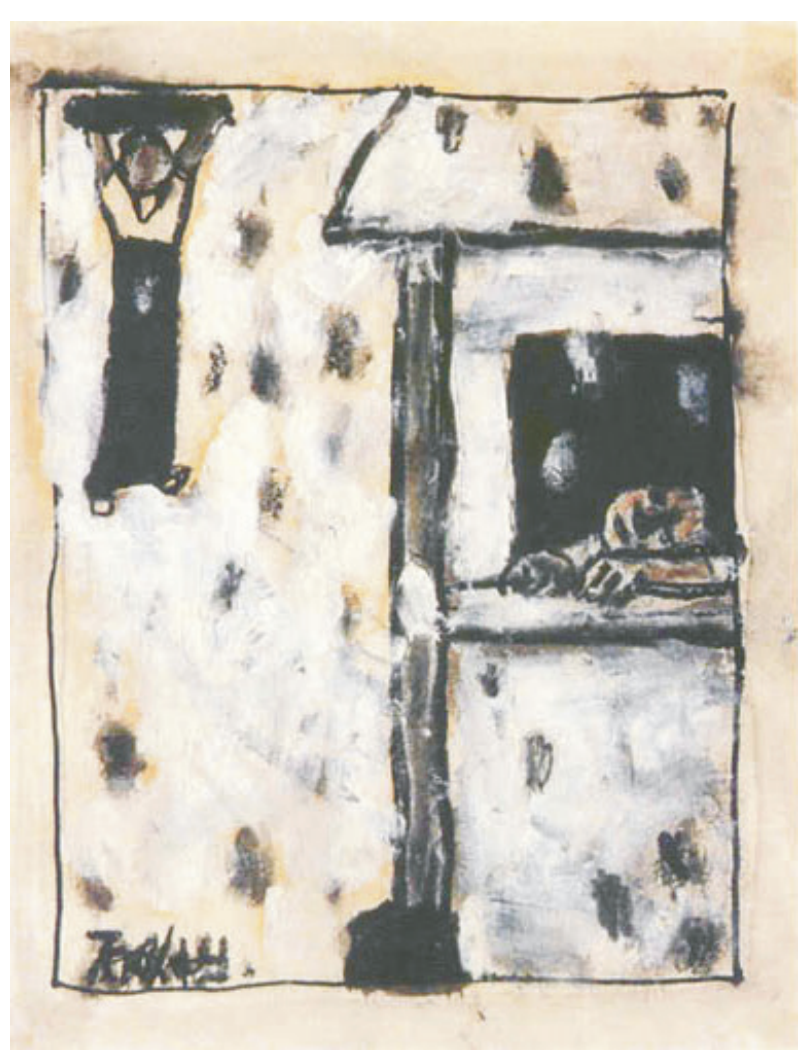

Figure 3. Jungseop Lee, <River of no return>, 1956, Oil, color pencil and pen on paper, $18.8 \times 14.6 \mathrm{~cm}$, Personal collection (presumed).

청량리뇌병원 모두에서 가장 우선시된 치료는 거식증에 대 한 치료로 보인다. 주치의였던 유석진에 따르면 이중섭이 입 원 당시 극심한 거식증으로 몸이 쇠약해져 맥이 잘 잡히지 않을 정도여서 코를 꽉 쥐어 입을 벌리는 순간 식도에 미음 을 집어넣거나 링거로 연명하게 할 수밖에 없었다고 하였다. 당시 정신질환에 대한 특수 약물은 없었다. 1955년 당시 이중섭의 유일한 치료방법은 경련요법이었다. 우리나라에서 는 약물이 도입되기 전인 1950년대에 인슐린혼수요법과 전 기경련요법(ECT)이 시행되고 있었다(Lee 1959). 이중섭은 성베드로병원에서 $\mathrm{ECT}$ 를 통해 3개월만에 성공적 치료결과 를 얻었다. 이중섭이 보였던 식사거부, 피해사고와 죄책망상 을 동반한 거절증 환자에게 현재도 ECT는 치료법으로 자주 사용되고 있다. 이중섭에게 ECT란 공포의 대상이었을 것이 다. 이중섭은 이에 대한 경험을 3편의 낙서화 〈모색〉, 〈모색 2〉, 〈힘, 전기스탠드〉에 ‘電氣stand(A)', “模索, ‘力’ 글자를 적어 넣었다. 이는 몸에 새로운 氣力이 통하듯이 활력을 느꼈다는 $\mathrm{ECT}$ 치료에 대한 긍정적 경험을 표현하였다고 볼 수 있다.

이밖에 유석진은 역동정신의학, 프로이트 정신분석을 이 중섭 치료에 적용하였을 것으로 생각된다. 유석진 원장은 이 중섭 보다 4살이 적지만 환자들이 치료자에게 보이는 전이 현상은 나이와 큰 상관이 없이 일어난다. 대부분의 환자들은
남자 의사를 자애로운 아버지, 혹은 건강을 돌봐주는 신과 같은 전지전능한 존재로 보게된다. 이중섭의 경우 자신이 충 분히 경험하지 못했던 아버지와의 관계를 투사하게 되면서 때로는 두려움을, 때로는 존경심을, 때로는 경쟁심과 질투를 느낄 수 있다. 이러한 이중섭의 심리는 주치의와의 관계를 상징하는 ‘한자 이름 낙서' 5 점에서 나타난다. 날짜순으로 변 화과정을 살펴보면 치유과정을 명확히 알 수 있다. 유(세)는 주치의 유석진, 이(李)는 본인, 김(金)은 항시 유(섹) 다음에 그리는 것으로 보아 수석 간호사, 황(黃)은 이(李)와 붙어 다 니는 것으로 보아 이중섭 담당 간호사 같다. 처음 그린 낙서 에서 마지막 5 번째 낙서로 변화과정을 요약하면, 처음 이름 순서배열에서 가장 후순위로 밀려 있고 글자 크기도 작고 희미했던 이(李)가 나중에는 순위가 황(黃)에 앞서 있고 글

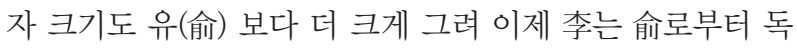
립되어 존재함을 표현한 것이다. 글자 놀이와 같은 이러한 낙서는 환자의 입장에서 볼 때 자신의 운명을 거머쥔 전재 전능한 아버지와 같은 주치의를 통해 콤플렉스가 어떻게 해 결되어가는지를 보여주었다는 점에서 큰 의미가 있다고 여 겨진다(Sohn 2016).

빈센트와 이중섭의 공통된 치료법은 화가의 특수성을 살 린 그림 그리기였다. 다만 이중섭의 경우 짧은 입원기간, 좁 은 병실공간, 화구재료 구입이 빈센트보다 열악하여 낙서화 수준의 연필, 잉크 스케치를 그렸지만 나름대로 치료과정의 진행을 보여주는 귀중한 자료를 남겼다. 한편으로 입원자체 에서 오는 규칙적인 수면, 식사, 금주가 두 화가의 회복에 큰 영향을 미쳤을 것이다.

\section{예술가의 창조성과 정신질환}

빈센트가 살던 19세기 후반기는 천재와 정신질환자 간의 관계에 대한 관심이 높았던 시기이다. Moreau는 정신질환자 와 천재 모두 뇌가 과흥분 상태라는 주장을 하였다(Moreau 1859). 이탈리아의 Lombroso는 더 나아가 간질, 정신질환, 천재 모두 뇌 변성(degeneration) 과정을 밟는 유전적 성향을 타고났다고 주장하였다(Lombroso 1864; Lombroso 1888). 즉 이 시기에는 정신질환, 간질, 천재성이 혼돈되었던 시기 였다. 20세기 들어 간질 정신질환 천재의 창의성이 구분 분 리되었다. 1980년대 이전에는 창의성과 관련된 정신병리로 조현병과 우울증에 대한 관심이 컸다. 그러나 1990년경부터 임상의들의 양극성장에 대한 진단이 급증하는 데에(Moreno 등 2007) 발맞추어 버지니아 울프(Virginia Wolf), 로베르 쉬 망(Robert Schuman), 조지 바이런(George Gordon Byron), 빈센트 등 예술가들의 일대기를 양극성장애의 관점에서 바 라보는 경우가 증가하였다. 따라서 20세기 후반부터는 양극 
성장애, 주요우울장애를 포함한 기분장애가 창의성과 관련 된 대표적인 정신병리현상으로 부상하였다(Post 1994).

창의적 시기와 경조증 시기는 많은 것을 공유하여 연상속 도의 증가, 새로운 아이디어, 원활한 생각의 흐름, 확장성 등 을 나타낸다. 많은 예술가들에서 창조성이 높아지면 기분이 고양되고 창조성이 부진하면 우울해지고, 역으로 기분이 고 양되면 창조성이 유발되고 우울하면 창의성이 떨어짐이 관 찰된다.

Jamison은 최고의 수상경력이 있는 문학가(시인, 극작가, 소설가), 화가 47 명을 대상으로 강한 창의성 기간이 있었는 지에 대한 질문에 89\%에서 이런 기간이 2주간 지속된 경우 가 가장 많았다고 하였다(Jamison 1989). 열정과 에너지의 증가, 자신감 상승, 연상 속도의 증가, 기분의 고양, 행복감 이 대부분에서 나타났지만, 경조증에서 특징적으로 나타나 는 과도한 성행동, 말이 많아짐, 과다 금전지출 같은 행동으 로 이어지는 경우는 매우 적어 '강한 창의성 삽화'와 '경조증 삽화'가 구분된다고 하였다. 또한 그는 정신과 치료경력이 없는 예술가들에 있어서 기분상승이 창의력을 높이지만, 정 신과 치료경력이 있는 예술가들의 경우에는 오히려 기분상 승이 창의성을 떨어뜨린다고 하였다(Jamison 1989). Andreason도 몇몇 작가들에서 경조증에 의한 에너지 증가가 창작성과로 집중되지 못하고 개인적인 일이나 주변인들과 의 관계에 소진된다고 하였다(Andreasen과 Canter 1974). 하지만 한 개인에서 '강한 창의성 삽화'인지 '경조증 삽화'인 지를 구분하기 어렵다. 또한 두 삽화가 근본적으로 다른 것 인지 심각도의 차이인지는 알 수 없다.

빈센트, 이중섭 두 화가 모두 경조증 삽화에는 작품 제작 활동이 늘어났다. 차이는 빈센트의 경우 경조증 시기에 과활 동이 지나쳐 전도사에서 해직되거나 밤새 언쟁을 벌여 사람 들을 질리게 하는 등 대인관계에 문제가 많았다. 이중섭의 1954년 가을 경조증 삽화에는 타인과의 충돌이 없는 상태에 서 다가올 개인전을 위해 창작 활동에 매진하였다. 따라서 일반인들은 이중섭의 이 시기를 병적인 경조증 상태가 아닌 개인전을 앞둔 창작열의 고조상태 시기로 간주할 것이다.

예술가들은 종종 자신의 기분장애 증상들을 예술적 기질 과 예민한 감수성으로 간주하여 정신과 치료를 받으면 혹시 나 창의성이 소멸되지 않을까 하는 우려심으로 특히 약물치 료에 저항하는 경우가 있다. 치료자는 기분장애의 긍정적 생 산적 측면이 있음을 인정해주고, 약물 부작용으로 인한 인지 기능 저하를 최소화할 경우, 오히려 훨씬 긴 기간 동안 창의적 작업에 참여할 수 있음을 알려 주어야한다. 일 예로 Schou는 lithium을 복용한 예술가 중 3/4에서 창작활동에 변화가 없거 나 증진되었고, $1 / 4$ 에서 창작활동력이 감소하였다고 하였다
(Schou 1979). 두 화가의 정신질환 치료가 그들의 예술적 작 업에 도움을 주었는지, 아니면 반대로 방해를 주었다고 생각 하는지에 대한 답은 편지에 있다. 빈센트는 편지에 "안정된 분위기에서 그림을 그리기 위해 병원에 입원하고 싶다”라고 썼으며, 이중섭의 경우 부인에게 보낸 마지막 편지에 "여러 친구들 덕분에 건강을 되찾아 1 주일 후 퇴원하오. 이제는 그 림도 그리고 씩씩하게 생활하니 기빼해주오, 4-5일후 그림 을 그려 보내주겠소”라며 그림을 다시 그릴 수 있게 회복시 킨 정신과적 치료에 긍정적이었다.

따라서 예민한 감수성과 감정기복이 흔한 예술인에 대한 정신과적 치료가 우울기를 줄이고 우울증으로 인한 자살을 막고, 경조증 상태에서 조증 상태로의 이행을 차단시킨다면 궁극적으로는 이들의 창작활동을 도와주고 창작기간을 연 장시키는 역할을 한다는 것이다. 두 화가에게 퇴원 후 지속 적 정신과 의사의 개입이 있었다면 더 오래 작품생활을 지 속할 수 있었겠다는 아쉬움이 남는다. 이중섭의 경우 우울증 에 빠져 자기 작품을 쓰레기라며 소각 훼손하는 행동도 막 았다면 그의 보다 많은 작품을 볼 수 있었으리라는 가정도 해볼 수 있겠다.

한 개인의 창의성과 정신질환문제를 언급할 때 주의할 점 은 예술가의 업적을 정신질환 혹은 신체질환 측면에서 과도 하게 해석하여 예술가의 업적을 폄하하거나 반대로 정신질 환에 대한 부인 내지 과소평가 태도도 견지하여야 한다.

아를 시절 해바라기를 비롯해 강한 노란색 사용 그림이 많은데 이를 digitalis 중독에 의한 황시증(xanthophobia)로 간주한다던지(Lee 1981), 〈밤의 카페〉 그림의 등잔불 광륜 (halo)을 일사병에 의한 백내장으로 추정한다 던지(Garrett 1971), 생레미 시절 올리브 나무, 사이프러스, 구름이 휘도는 소위 소용돌이치는 표현기법을 광기의 발산 혹은 메니에르 병으로 본다 던지(Arenberg 등 1990), 오베르 시절의 몇몇 그림이 아를 시절에 비해 정교하지 못한데 이를 납중독으로 인한 퇴행성 뇌병변(Weissman 2008)으로 간주하는 일부 연 구자들이 있다. 하지만 동시기의 다른 그림들을 비교해보거 나 전체적 삶의 맥락에서 볼 때 이들 주장들은 대부분 단편 적인 사실을 기반으로 하여 근거가 거의 없다.

두 화가의 생을 종합적인 관점에 입각하여 볼 때 지금까지 살펴본 것은 주로 병리현상 측면이다. 추가해야 할 것은 종 교 철학을 포함한 정신세계와 예술적 창조성이다. 이를 간과 하고는 빈센트나 이중섭의 작품을 논할 수 없다. 두 화가의 삶을 정신병리현상이 아닌 창조적이고 영적인 측면에서 살 펴보면 빈센트의 경우, 영혼 구제, 신성한 노동의 가치 실현 혹은 이들의 결합이 삶의 동기였고(Lewis 2017), 이중섭의 경우 정령사상, 범생명주의, 윤회설의 영적 바탕위의 삶이었 
다(Youn 2004). 두 화가의 삶은 현실적 어려움 속에서 질병 과 투쟁하면서 화가로서 자신의 삶의 목표와 예술적 창조력 을 추구하고 유지하려는 투쟁이었다라고 요약할 수 있겠다.

\section{결 론}

저자들은 두 화가의 일생, 가족, 병전 성격, 시대적 배경, 편지내용, 입원 전 문제행동, 입원 시 보인 정신증상, 진단, 정신역동, 치료방법, 예술가의 창조성과 정신질환에 대해 살 펴보았다. 이를 통해 두 화가 모두에서 나타나는 공통된 정 신질환은 양극성장애와 알코올을 포함한 물질중독장애 소 견이었다. 빈센트의 경우 schizoaffective bipolar type, 이중 섭의 경우 bipolar II 가능성이 제기되었다. 두 화가의 경우 경조증 상태에서는 일반적으로 창작열이 높아져 작품활동 이 증가하였고, 우울상태에서는 창작열이 떨어졌다. 빈센트 의 경우 초기부터 정신과적 치료에 대해 호의적이었으며, 이 중섭의 경우도 초반에 저항을 보였지만 결국 회복되어 창작 활동을 이어갔다. 양극성장애 예술인 본인 및 주변 지인들은 감정기복, 물질남용, 자살방지를 위한 정신과 의사의 지속적 관리가 그들의 창조성을 지속적으로 유지하는데 도움이 된 다는 사실을 반드시 인지하여야 하겠다. 정신역동면에서 빈 센트의 경우 출생 1 년전 사산된 형의 존재로 인한 교체(replacement)된 아이, 죽은 형의 망령과 함께 가야하는 이중성 (double)에 대해 언급하였으며, 이중섭의 경우 만 2세전 아 버지의 부재로 인한 미해결된 오이디푸스 콤플렉스를 보여 주는 거세공포 작품들과 정신증상에 대해 살펴보았다. 또한 한 개인의 창의성과 정신질환문제를 언급할 때 주의할 점은 예술가의 업적을 정신질환 혹은 신체질환 측면에서 과도하 게 해석하여 예술가의 업적을 폄하하거나, 반대로 정신질환 에 대한 부인 내지 과소평가하는 태도도 견지하여야 한다. 두 화가의 삶은 현실적 어려움 속에서 질병과 투쟁하면서 화가로서 자신의 삶의 목표와 예술적 창조력을 추구하고 유 지하려는 투쟁이었다라고 결론지을 수 있겠다.

\section{Acknowledgments}

본 연구는 대한신경정신의학 연구재단 지산 이세종 문화정신의 학 연구기금 지원에 의하여 수행되었음.

본고 작성을 위한 문헌정보 자료수집 및 정리를 도와준 의국비 서 강나루에게 감사 드립니다.

\section{Conflicts of Interest}

The authors have no potential conflicts of interest to disclose.

\section{Author Contributions}

Conceptualization: Young Sik Lee. Data curation: Young Sik Lee, Hyunchan Hwang. Funding acquisition: Young Sik Lee. Investigation:
Young Sik Lee. Methodology: Young Sik Lee. Writing-original draft: Young Sik Lee. Writing - review \& editing: Young Sik Lee, Hyunchan Hwang.

\section{ORCID iDs}

Young Sik Lee

https://orcid.org/0000-0003-2161-8232

Hyunchan Hwang

https://orcid.org/0000-0001-6514-5188

\section{REFERENCES}

American Psychiatric Association. Diagnostic and statistical manual of mental disorders. 5th ed. Washington DC: American Psychiatric Publishing;2013.

Andreasen NJ, Canter A. The creative writer: psychiatric symptoms and family history. Compr Psychiatry 1974;15:123-131.

Arenberg IK, Countryman LF, Bernstein LH, Shambaugh GE Jr. Van Gogh had Menière's disease and not epilepsy. JAMA 1990;264:491493.

Arnold WN. Vincent van Gogh: chemicals, crises, and creativity. Basel: Birkhäuser;1992.

Blum HP. Van Gogh's fantasies of replacement: being a double and a twin. J Am Psychoanal Assoc 2009;57:1311-1326.

Blumer D. The illness of Vincent van Gogh. Am J Psychiatry 2002;159: 519-526.

Cain AC, Cain BS. On replacing a child. J Am Acad Child Psychiatry 1964; 3:443-456.

Choi Y. A critical biography on Jungseop Lee. Paju: Dolbegae;2014.

EBS Knowledge Channel e Creative Team. EBS children's knowledge e. 7. Gwangmyeong: Jisik Plus;2015.

Garrett G. Vincent van Gogh and glaucoma. JAMA 1971;218:595-596.

Gastaut H. Vincent van Gogh's disease seen in the light of new concepts of psychomotor epilepsy. Ann Med Psychol (Paris) 1956;114:196-238.

Go E. 이중섭 그 예술과 생애. Seoul: Mineumsa;1973.

Go E. 이중섭 평전. Seoul: Hyangyeon;2004.

Hong EH. 화가 이중섭 정신질환 있었다한국임상예술학회 토론회 분석. [updated 1993 July 9; cited 2021 September 1]. Available from: https://www.joongang.co.kr/article/2824663\#home.

Jamison KR. Mood disorders and patterns of creativity in British writers and artists. Psychiatry 1989;52:125-134.

Jaspers K. Strindberg und van Gogh. Annalen der Philosophie Und Philosophischen Kritik 1926;5:220.

Jo JJ. Life and art of Jungseop Lee. [master's thesis]. Seoul: Hongik University; 1971.

Kang WH. 천재화가 이중섭과 아이들. Seoul: Yearimdang;1999.

Kim GL. 나의 이중섭 체험. Seoul: Yuwon;1977.

Kwack Y. 이중섭 회화의 상징성. Korean Bulletin of Clinical Art 1985; 1:50-65.

Kwon KY. 역시 단원·혜원 $\cdots$ 디지털 미술관서도 시선 집중. [updated 2014 July 7; cited 2021 September 1]. Available from: https://www. joongang.co.kr/article/15178153\#home.

Lee BY. 이중섭의 회화에서 본 그리움의 의미-위기와 창조성과의 관 련에서. 표현정신병리 국제심포지움 및 미술치료법워크샵 1994; 46-63.

Lee H. 이중섭(李仲狺)의 사랑과 예술. Seoul: Baikmisa;1981.

Lee J (Trans. Park JS). 이중섭, 그대에게 가는 길. Seoul: Davinci;2000.

Lee J (Trans. Yang UK). 이중섭 편지. Seoul: Hyunsilbook;2015.

Lee JG. 정신신경과영역의 최신치료경향. 한국의약 1959;2:31-34.

Lee MS. Psychoanalytic study on the life of Vincent Van Gogh. Psychoanal 1997;8:146-162 .

Lee TC. Van Gogh's vision. Digitalis intoxication? JAMA 1981;245:727729.

Lee YS. The review of Vincent van Gogh's mental world and mental illness in the viewpoint of modern psychiatry. J Korean Neuropsychiatr Assoc 2021;60:97-119. 
Lewis B. A deep ethics for mental difference and disability: the 'case' of Vincent van Gogh. Med Humanit 2017;43:172-176.

Lombroso C. Genio e follia, in rapporto alla medicina legale, alla critica ed alla storia [Genious and Madness in Medicine Legacy, Criticism and History]. Milano: Giuseppe Chiusi;1864.

Lombroso C. L'uomo di genio in rapporto alla psichiatria, alla storia ed all'estetica (Vol. 4). Torino: Fratelli Bocca; 1888.

Mehlum L. Suicidal process and suicidal motives. Suicide illustrated by the art, life and illness of Vincent van Gogh. Tidsskr Nor Laegeforen 1996;116:1095-1101

Meissner WW. The theme of the double and creativity in Vincent van Gogh. Contemp Psychoanal 1994;30:323-347.

Min GH. 빈센트 반 고흐, 내 영혼의 자서전. Seoul: Hakgojae;2000.

Moreau JJ. La psychologie morbide dans ses rapports avec la philosophie de l'histoire: ou, de l'influence des névropathies sur le dynamisme intellectuel. Paris: Masson; 1859.

Moreno C, Laje G, Blanco C, Jiang H, Schmidt AB, Olfson M. National trends in the outpatient diagnosis and treatment of bipolar disorder in youth. Arch Gen Psychiatry 2007;64:1032-1039.

Na KS, Paik JW, Yoon MK, Kim HS. Psychological autopsy: review and considerations for future directions in Korea. J Korean Neuropsychiatr Assoc 2015;54:40-48.

Nomura A (Trans. Kim SW). 고흐, 37년의 고독. Seoul: Kungul;2004.
Park HK. 내친구 빈센트. Goyang: Sonamoo;1999.

Post F. Creativity and psychopathology. A study of 291 world-famous men. Br J Psychiatry 1994;165:22-34.

Schou M. Artistic productivity and lithium prophylaxis in manic-depressive illness. Br J Psychiatry 1979;135:97-103.

Sohn S. Psychological Autopsy of Lee Jung Sup's Death. Association of Biographical Art History in Korea 2016;12:185-329.

Sund J (Trans. Nam GT). Van Gogh. Paju: Hangilart;2004.

van Meekeren E. Starry starry night: life and psychiatric history of Vincent van Gogh. Amsterdam: Benecke NI;2003.

Weissman E. Vincent van Gogh (1853-90): the plumbic artist. J Med Biogr 2008; 16:109-117.

Youn BM. A study on Lee, Joong-Seob's painting. Dongak Art History 2004;5:191-204.

Gu S. 이중섭(李仲夏)의 발병(發病) 전후: ‘성당부근(聖堂附近)'에 대 하여. 문학사상 1974;23:342.

JoongAng Daily. 초중고 학생 76\%가 미술학원 “과외경험”. [updated 1988 July 28; cited 2021 September 1]. Available from: https://www. joongang.co.kr/article/2262408.

Chosunilbo. 故 李仲樂화백「鬪病그림」전시. [updated 1973 Decmeber 16; cited 2021 Septermber 1]. Available from: https://newslibrary.chosun.com/view/article_view.html?id=1621619731216m10713\&set_ date $=19731216 \&$ page no $=7$. 